\title{
НОВЫЕ ДАННЫЕ ПО ГЕОХИМИИ И УСЛОВИЯМ ОБРАЗОВАНИЯ ГЕРМАНИЙ-УГОЛЬНОГО МЕСТОРОЖДЕНИЯ СПЕЦУГЛИ (ПРИМОРСКИЙ КРАЙ)
}

\author{
Арбузов Сергей Иванович1, \\ siarbuzov@mail.ru
}

Чекрыжов Игорь Юрьевич2, chekr2004@mail.ru

Ильенок Сергей Сергеевич1, ilenokss@tpu.ru

\section{Соктоев Булат Ринчинович1, bulatsoktoev@tpu.ru}

\section{Соболева Елена Евгеньевна3,} SobolevaEE@suek.ru

1 Национальный исследовательский Томский политехнический университет, Россия, 634050, г. Томск, пр. Ленина, 30.

2 Дальневосточный геологический институт ДВО РАН, Россия, 690022, г. Владивосток, пр. 100-летия Владивостоку, 159.

3 РУ «Новошахтинское» ООО «Приморскуголь»,

Россия, 690090, г. Владивосток, ул. Тигровая, 29.

Актуальность исследования обусловлена необходимостью разработки прогнозно-поисковых критериев для выявления стратегически важного типа германиевого сырья - германий-угольных месторождений.

Цель: изучить геохимические особенности и условия образования комплексного редкометалльного оруденения в углях месторождения Спецугли (Дальний Восток) и на его примере разработать геолого-геохимическую модель формирования месторождений подобного типа.

Объекты: угли, углевмещающие породы, подземные воды и породы фундамента германий-угольного месторождения. Методы: геолого-геохимическое изучение и опробование, масс-спектрометрия с индуктивно связанной плазмой, инструментальный нейтронно-активационный анализ, сканирующая электронная микроскопия, оптическая микроскопия, рентгенофазовый анализ, корреляционный анализ.

Результаты. Получены новые данные по геологическому строению и особенностям геохимии углей и углевмещающих пород германий-угольного месторождения Спецугли в Приморье. Обоснован комплексный полиэлементный состав редкометалльного оруденения, согласующийся с особенностями геохимии и минерагении пород фундамента и обрамления Павловской впадины. Для металлоносных уелей характерны аномально высокие, превышающие в десятки и сотни раз средние содержания для бурых уәлей мира, концентрации $\mathrm{Ge}, \mathrm{Sb}, \mathrm{Hg}, \mathrm{W}, \mathrm{Li}, \mathrm{Be}, \mathrm{Cs}$, u As. Менее аномальны уровни накопления U, Mo, Y, Rb, лантаноидов, Zn u Ga. Выполненный комплексный минералого-геохимический и геолого-структурный анализ особенностей состава и строения Ge-угольного месторождения Спецугли позволил пересмотреть принятую гидротермальную модель его образования и обосновать предложенную ранее гипергенную модель, когда источником металлов являются породы фрундамента, вмещающие угольные месторождения. Формирование $\mathrm{Ge}$ и сопутствующего оруденения в месторождении Спецугли происходило под влиянием формирующейся коры выветривания по редкометалльному граниту вознесенского комплекса, прорванному дайками позднепермского возраста. Месторождение приурочено к возвышенности гранитного состава, образуя концентрически-зональный ореол $\mathrm{Ge}$ и сопутствующих элементов вокруг неё. Граниты подвергнуты гидротермальнометасоматическим изменениям докайнозойского возраста с формированием квари-альбит-микроклиновых метасоматитов и грейзенов, содержащих W-Mo и Hg-Sb-As минерализацию. Образование редкометалльного оруденения в углях связано с формированием каолиновой коры выветривания по гранитам, выносом и переотложением основных элементов в окружающие палеоторфяники в палеогеновое время.

\section{Ключевые слова:}

Германий-угольное месторождение, уголь, геохимия, редкие элементы, редкометалльное оруденение, условия образования, гидрогенная модель.

\section{Введение}

Германий - основной попутный элемент в углях, извлечение которого освоено промышленностью. Германий-угольное месторождение Спецугли, открытое в середине 60-х гг. прошлого столетия, в настоящее время является одним из крупнейших в мире и единственным отрабатываемым месторождением такого типа в Российской Федерации. Аналогичные месторождения известны и эксплуатируются в Китае [1-5]. Их отличительной особенностью является комплексный характер руд, включающих помимо германия также вольфрам, бериллий, сурьму и другие ценные элементы-примеси. 
Несмотря на более чем полувековой период изучения месторождения Спецугли и промышленную отработку значительной его части, дискуссии о природе его формирования не прекращаются. Основным вопросом, не решенным до настоящего времени, является природа источника германия и других сопутствующих элементов. По одним представлениям это продукты коры выветривания пород обрамления бассейна, по другим - гидротермальные растворы. Первая модель, обоснованная на первом этапе изучения месторождения, получила название гипергенной [6-8]. Вторая модель появилась несколько позднее, хотя и почти одновременно с гипергенной, и названа гидротермально-осадочной, эксгаляционно-осадочной или эксфильтрационной [9-18 и др.]. В основу ее изначально были положены результаты исследования распределения повышенных содержаний германия в торфах Налычевской депрессии полуострова Камчатка в зоне влияния термального источника [9]. Привлекательность этой модели обусловлена сходством геохимических ассоциаций, характерных для большинства германий-угольных месторождений мира, объясняемых привносом этих элементов синхронными угленакоплению гидротермами.

В настоящее время на месторождении Спецугли ведется разработка германиеносных углей открытым способом. Месторождение вскрыто карьером на полную глубину, в том числе вскрыт фундамент, что позволяет не только моделировать, но визуально наблюдать и изучать строение месторождения, картировать следы различных геологических процессов, протекавших здесь в различные геологические периоды. Данная работа посвящена анализу новых, полученных в последнее десятилетие геолого-геохимических данных с целью сравнения двух основных гипотез образования месторождения и разработке геологогеохимической модели его формирования. Решение этого вопроса имеет не только большое научное значение, но и чрезвычайно важно для решения задачи поисков подобного оруденения на других площадях и в других регионах.

\section{Особенности геологического строения месторождения}

Месторождение германия Спецугли расположено на юго-западной окраине Ханкайского срединного массива в непосредственной близости от Вознесенского рудного района, известного своими месторождениями $\mathrm{W}, \mathrm{Sn}$ и флюорита, связанными с палеозойским гранитоидным магматизмом. Месторождение расположено в восточной части Павловской впадины (рис. 1), одной из депрессий, составляющих Павловское угольное поле [19]. Общие особенности геологического строения германий-угольного месторождения Спецугли в пределах Павловского буроугольного месторождения достаточно детально описаны в многочисленных работах [7, 17, 20-22].

Фундамент. Фундамент Павловской впадины гетерогенный. Представлен кембрийскими осадочновулканогенными толщами григорьевской серии, сложенной кварц-серицитовыми, серицит-хлоритовыми, углисто-графитовыми сланцами, песчаниками, алев- ролитами, туфами, туффитами, лавобрекчиями кислого состава и, редко, прослоями известняков [23]. Важную роль в строении фундамента также играют магматические породы, преимущественно палеозойские гранитоиды (рис. 1).

Непосредственно на участке Спецугли фундамент достаточно однороден по составу. Представлен он средне-крупнозернистыми гранитами с единичными дайками предположительно андезитового состава и хорошо развитой каолиновой корой выветривания. Мощность коры выветривания достигает 40-50 м [12] Граниты биотитовые, грейзенизированные. В связи с этим комплексом за пределами вскрытой части фундамента описаны также скарновые тела, распространенные в зоне контакта гранитоидов с карбонатными породами. Рельеф фундамента впадины сильно дифференцирован. Имеют место возвышенности и пониженные в палеорельефе участки. Относительное превышение поднятий над долинами составляет 40-80 м. В связи с этим мощность осадочных отложений кайнозоя колеблется на участке от 42 до 200 м [12]. В пределах месторождения и в непосредственной близости от него выделены 5 поднятий, одно из которых расположено в центре месторождения Спецугли. Характер расположения возвышенностей в фундаменте позволяет рассматривать их как реликты водораздела существовавшей до формирования Павловской впадины речной сети. Отсутствие в фундаменте и перекрывающих отложениях постугольных разрывных нарушений, а также следов конседиментационной складчатости не дает оснований для отнесения этих возвышенностей к конседиментационным поднятиям [11], а позволяет рассматривать их как реликты водораздела древней гидросети.

В настоящее время угледобывающим разрезом вскрыт участок фундамента в пределах центрального поднятия. На участке хорошо сохранилась элювиальная кора выветривания по гранитам. Отчетливо видна реликтовая структура средне- крупнозернистого гранита без следов тектонических нарушений (зон брекчирования, катаклаза, милонитизации). Хорошо проявлена вертикальная зональность коры выветривания, выраженная в смене зоны дезинтеграции гидрослюдисто-каолинитовой и каолинитовой зоной. Реликтовая структура гранита сохраняется по всему разрезу. В центре возвышенности под корой выветривания имеется останец слабо выветрелого грейзенизированного гранита. Гранит, согласно классификации TAS, относится к группе от нормально-щелочных до умеренно щелочных лейкогранитов. Сумма щелочей составляет 6,9-8,6 \%, содержание кремнезема 73-76 \% (табл. 1).

В границах вскрытого разрезом гранитного тела также имеется выход дайки предположительно андезитового состава с хорошо сохранившейся мелкозернистой реликтовой структурой. Следов тектонической активности после формирования коры выветривания с формированием зон дезинтеграции - путей миграции термальных растворов - не выявлено. Гидротермально-метасоматической зональности, обусловленной гидротермальными процессами после 
формирования коры выветривания в пределах пород фундамента, также не установлено. Исходные, не подвергшиеся выветриванию, граниты, изученные в останце, подвержены альбитизации, микроклинизации и наложенной на них грейзенизации. Грейзенизация проявлена слабо, преимущественно в виде развития мусковита по полевому шпату, хлоритизации биотита и формировании специфической акцессорной минерализации. Ранние альбит-микроклиновые метасоматические преобразования сопровождаются также формированием вторичного зеленого биотита. В грейзенизированных гранитах установлена разнообразная минерализация, представленная сульфидами: молибденитом, мышьяковистым пиритом, галенитом, а также касситеритом, фосфатами и фторкарбонатами редкоземельных элементов.

Возраст гранитов из центрального поднятия, определенный U-Pb методом (SHRIMP-II, АЦ ВСЕГЕИ),

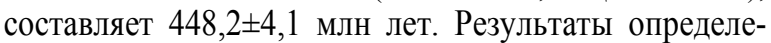
ния изотопного возраста, наряду с геохимическими особенностями гранитов, позволяют отнести их к вознесенскому комплексу редкометалльных протилитионитовых гранитов [24-26]. Исследованные граниты отличаются аномальной радиоактивностью. В изученных образцах содержание тория изменяется от 38,8 до 118 г/т, урана - от 10 до 37,6 г/т (табл. 2).
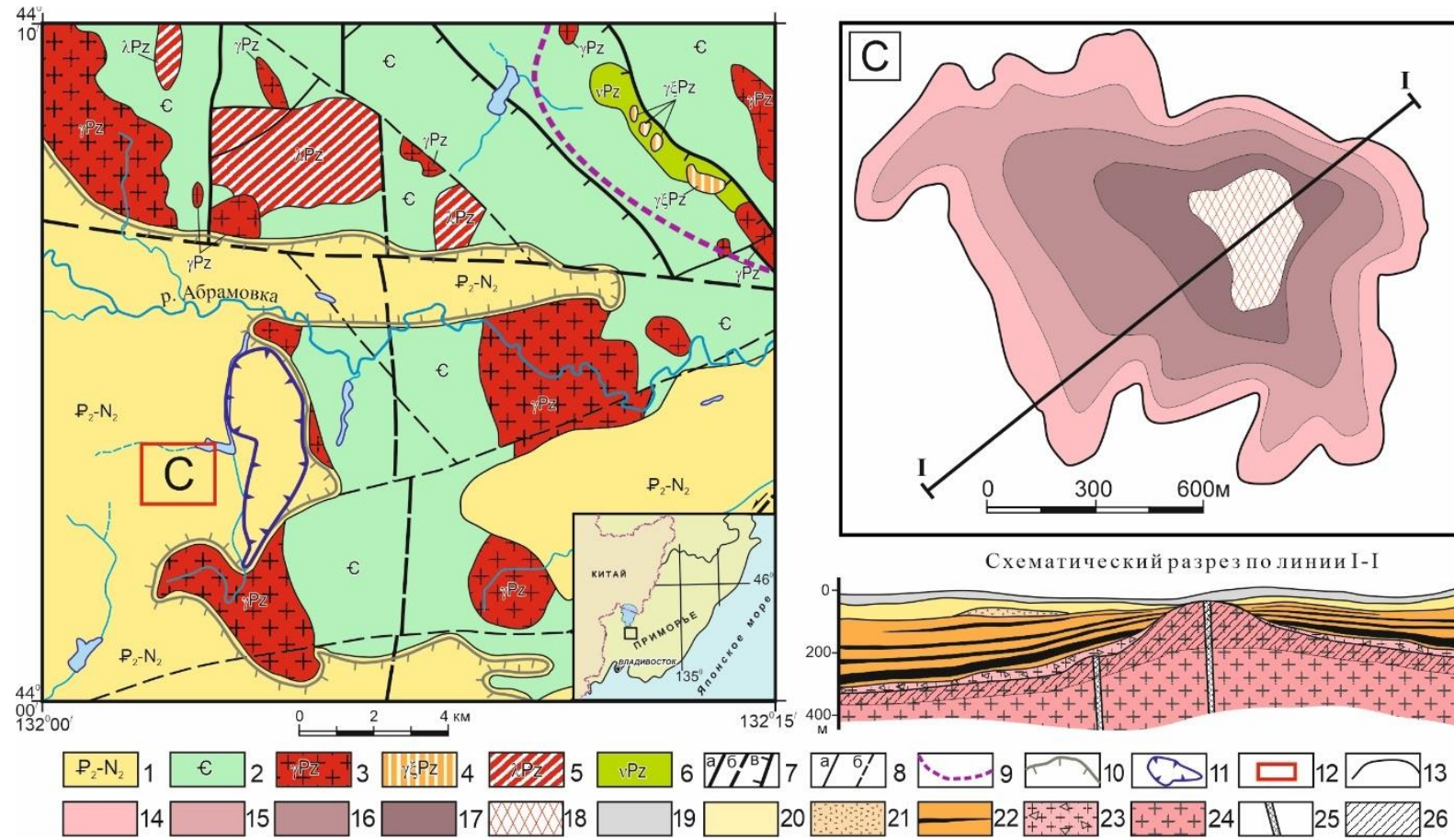

Схематический разрезполинии I-I

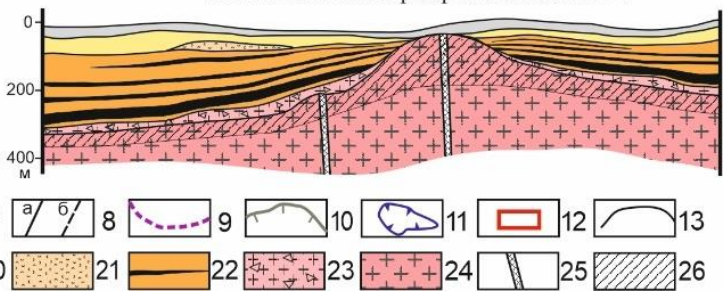

Рис. 1. Геологическая карта района (по [23] с изменениями и дополнениями авторов), схема распределения германия и геологический разрез месторождения Спецугли. Условные обозначения: 1 - палеоген-неогеновые песчаногалечниковые (неоген) и угленосные отложения (песчаники, алевролить, аргиллить и угли) (палеоген); 2 -кембрийские отложения (сланцуы серицитовые, квари-серицитовые, углеродистые, алевролиты, линзы известняков); Палеозойские магматические породы: 3 - граниты; 4 -граносиениты; 5 - риолиты; 6 - габбро и габбро-диорить; 7 - главные разломы: а -достоверные, б-предполагаемьле, в-надвиги; 8 - второстепенные разломы: : а-установленные, б - предполагаемые; 9 - Вознесенский рудный район; 10 - граница угленосных отложений Павловского угольного поля; 11 - рабочий участок Павловский-2; 12 - контур участка месторождения Спецугли (C); 13 - контур промышленного оруденения с содержанием Gе в углях (2/m): 14 - >50; 15 - >200; 16 - >400; 17 - >1000; 18 - выход фундамента; Отложения: 19 - современные рыхлые; 20 - неогеновые слабо литифицированные; 21 -линзы туфов и туффитов; 22 - палеогеновые угленосные; 23 - переотложенная кора выветривания; 24 - интрузивные породы (граниты); 25 - дайки; 26 - кора выветривания

Fig. 1. Geological map of the studied area (by [23] with changes and supplements of the authors), scheme of Ge distribution and geological cross-section of the Spetsugli deposit. Legend: 1 - Paleogene-Neogene sandy-pebble (Neogene) and coal-bearing sediments (sandstones, siltstones, claystones and coals) (Paleogene); 2 - Cambrian sediments (sericite, quartz-sericite and carbonaceous slates, siltstones, limestone lenses); Paleozoic magmatic rocks: 3 - granites; 4 - granosyenite; 5 - rhyolite; 6 - gabbro and gabbro-diorite; 7 - major faults: a - proven, 6 - predicted, в- overthrusts; 8 - secondary faults: a - determined, 6 - predicted; 9 -Voznesenky ore district; 10 - boundary of coal-bearing deposits of the Pavlovskoe coal field; 11 - Pavlovsky-2 working area; 12 - contour of the Spetsugli deposit area $(C) ; 13$ - contour of the industrial mineralization with the Ge content in coals (ppm): 14 - >50; 15 - >200; 16 - >400; 17 - >1000; 18 -foundation outcrop; Deposits: 19 - modern soft sediments; 20 - Neogene slightly lithified sediments; 21 - tuff and tuffite lenses; 22 -Paleogene carbonaceous sediments; 23 - redeposited weathering crust; 24 - intrusive rocks (granites); 25 - dikes; 26 - weathering crust 
Таблица 1. Химический состав слабо измененных гранитов фундамента месторождения Спеиуг$л и, \%$

Table 1. Chemical composition of weakly altered granites from the foundation of the Spetsugli deposit, \%

\begin{tabular}{|l|c|c|c|c|}
\hline $\begin{array}{c}\text { Компоненты } \\
\text { Components }\end{array}$ & CУ-81-19A & CУ-81-19B & CУ-81-19C & CУ-55-18 \\
\hline $\mathrm{SiO}_{2}$ & 73,01 & 76,17 & 75,31 & 74,56 \\
\hline $\mathrm{TiO}_{2}$ & 0,52 & 0,14 & 0,34 & 0,27 \\
\hline $\mathrm{Al}_{2} \mathrm{O}_{3}$ & 11,11 & 11,60 & 11,82 & 13,63 \\
\hline $\mathrm{Fe}_{2} \mathrm{O}_{3}$ & 6,10 & 2,69 & 3,21 & 1,22 \\
\hline $\mathrm{MnO}$ & 0,13 & 0,03 & 0,05 & 0,03 \\
\hline $\mathrm{CaO}$ & 0,49 & 0,16 & 0,56 & 0,25 \\
\hline $\mathrm{MgO}$ & 0,48 & 0,12 & 0,19 & 0,13 \\
\hline $\mathrm{K}_{2} \mathrm{O}$ & 4,05 & 6,17 & 3,85 & 5,13 \\
\hline $\mathrm{Na}_{2} \mathrm{O}$ & 2,85 & 2,46 & 3,44 & 3,06 \\
\hline $\mathrm{P}_{2} \mathrm{O}_{5}$ & 0,09 & 0,05 & 0,10 & 0,08 \\
\hline $\mathrm{H}_{2} \mathrm{O}-$ & 0,04 & 0,07 & 0,17 & 0,28 \\
\hline$\Pi$ ПП/LOI & 1,05 & 0,27 & 0,53 & 1,04 \\
\hline $\mathrm{CyMma/Sum}$ & 99,91 & 99,92 & 99,57 & 99,68 \\
\hline $\mathrm{K}_{2} \mathrm{O}+\mathrm{Na}_{2} \mathrm{O}$ & 6,90 & 8,63 & 7,29 & 8,19 \\
\hline
\end{tabular}

Примечание: ППП - потери при прокаливании.

Note: LOI-losses of ignition.

Исследованные образцы двуслюдяного гранита отличаются также аномально высоким содержанием большой группы редких элементов (РЗЭ, Y, Be, Rb, $\mathrm{Cs}, \mathrm{Nb}, \mathrm{Se}, \mathrm{Hf}), \mathrm{W}, \mathrm{Sn}$ и элементов-халькофилов (Mo, Pb, Sb, Ag, As, Co).

Возраст дайки в гранитах, определенный $\mathrm{U}-\mathrm{Pb}$ методом (SHRIMP-II, АЦ ВСЕГЕИ), составляет $263 \pm 1,6$ млн лет, что соответствует поздней перми. Ранее эти дайки рассматривались как дайковый комплекс позднего мела [12] и даже кайнозоя [28]. С ними связывалось гидротермальное редкометалльное оруденение в обрамлении Павловской впадины и в угленосных отложениях на участке Спецугли [17, 28]. Как следует из полученных новых данных, формирование даек существенно оторвано по времени от периода углеобразования.

Крупных тектонических нарушений в пределах осадочного чехла кайнозойского возраста вблизи месторождения не выявлено [23]. Нет сведений и о наличии таковых в фундаменте в пределах этого участка угленосной впадины. Тем не менее некоторая тектоническая активность отмечается на исследуемой территории не только наличием здесь позднепалеозойских даек, но и общим наклоном угленосных отложений от 2 до $12^{\circ}$ в западном направлении к центру угленосной впадины, а также наклоном фундамента в том же направлении. Тектоническая активность, выразившаяся в формировании зон катаклаза и милонитизации в палеозойских гранитоидах и кембрийских сланцах, проявлена и в горно-складчатом обрамлении Павловской впадины. В связи с ней известно гидротермальное (?) РЗЭ оруденение в дайках и сопутствующих им аргиллизитах к востоку от участка Павловский-2 Павловского буроугольного месторождения [28]. Тектонические активные зоны сдвигового характера постугольного заложения выявлены в пределах того же участка в 2 км к северо-западу от месторождения Спецугли, а также на участке Южном [20].
Таблица 2. Содержание микроэлементов в гранитах фундамента, г/m

Table 2. Content of trace elements in the granites of the foundation, ppm

\begin{tabular}{|c|c|c|c|c|c|c|c|}
\hline 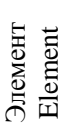 & $\begin{array}{l}\frac{a}{1} \\
\hat{\sigma} \\
\dot{0} \\
\dot{0}\end{array}$ & $\begin{array}{l}\overleftrightarrow{\vdots} \\
\frac{1}{1} \\
\infty \\
i \\
\vdots\end{array}$ & $\begin{array}{l}\frac{m}{2} \\
\frac{1}{1} \\
\infty \\
i \\
0\end{array}$ & 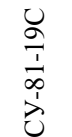 & 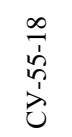 & 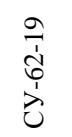 & 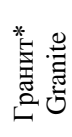 \\
\hline $\mathrm{Li}$ & 52,4 & 92,6 & 27,0 & 36,7 & 28,1 & 45,5 & 37,0 \\
\hline $\mathrm{Be}$ & 6,7 & 6,1 & 3,2 & 8,3 & 3,9 & 6,0 & 3,6 \\
\hline $\mathrm{Sc}$ & 14,1 & 18,2 & 5,9 & 8,9 & 8,1 & 8,0 & 6,5 \\
\hline $\mathrm{V}$ & 19,1 & 32,1 & 13,8 & 16,0 & 6,8 & 18,0 & 38,0 \\
\hline $\mathrm{Cr}$ & 7,1 & 8,5 & 7,6 & 3,1 & 6,2 & 4,2 & 5,6 \\
\hline Co & 55,6 & 34,2 & 15,1 & 60,0 & 14,3 & 1,2 & 1,0 \\
\hline $\mathrm{Ni}$ & 4,5 & 4,3 & 4,1 & 5,6 & 0,4 & 1,2 & 3,5 \\
\hline $\mathrm{Cu}$ & 5,8 & 11,4 & 10,0 & 21,0 & 4,0 & 3,7 & 10,0 \\
\hline $\mathrm{Zn}$ & 69,7 & 100,1 & 37,9 & 59,9 & 49,6 & 56,0 & 39,0 \\
\hline $\mathrm{Ga}$ & 30,0 & 30,6 & 24,2 & 34,6 & 36,3 & 36,7 & 18,0 \\
\hline $\mathrm{Ge}$ & 3,0 & 2,4 & 1,9 & 2,7 & 25,7 & 3,2 & 2,8 \\
\hline As & 35,2 & 3,5 & 3,1 & 9,5 & 72,8 & 2,6 & 1,6 \\
\hline $\mathrm{Se}$ & 8,9 & 6,0 & 1,6 & 12,8 & 47,5 & 4,9 & 0,07 \\
\hline $\mathrm{Rb}$ & 396 & 386 & 593 & 327 & 311 & 357 & 180 \\
\hline $\mathrm{Sr}$ & 101 & 80 & 89 & 98 & 82 & 49,3 & 150 \\
\hline $\mathrm{Y}$ & 378 & 270 & 101 & 156 & 467 & 154 & 50 \\
\hline $\mathrm{Zr}$ & 130 & 230 & 100 & 94 & 193 & 219 & 180 \\
\hline $\mathrm{Nb}$ & 35,9 & 76,3 & 29,8 & 51,6 & 38,4 & 57,7 & 21 \\
\hline Mo & 3,7 & 5,0 & 7,4 & 4,7 & 1,8 & 0,48 & 1,5 \\
\hline $\mathrm{Ag}$ & 0,46 & 0,48 & 0,26 & 0,18 & 0,21 & 0,27 & 0,038 \\
\hline $\mathrm{Cd}$ & 0,75 & 0,42 & 0,58 & 0,29 & 0,27 & 0,14 & 0,17 \\
\hline $\mathrm{Sn}$ & 9,4 & 14,6 & 4,9 & 8,9 & 6,0 & 11,9 & 3,0 \\
\hline $\mathrm{Sb}$ & 4,9 & 1,7 & 1,0 & 2,7 & 7,4 & 1,2 & 0,2 \\
\hline Cs & 7,0 & 8,1 & 5,5 & 6,0 & 7,1 & 11,2 & 5,0 \\
\hline $\mathrm{Ba}$ & 397 & 314 & 463 & 294 & 406 & 242 & 750 \\
\hline $\mathrm{La}$ & 414 & 261 & 196 & 652 & 1063 & 207 & 48 \\
\hline $\mathrm{Ce}$ & 1124 & 609 & 338 & 1193 & 991 & 95,3 & 72 \\
\hline Pr & 79,1 & 62,8 & 44,7 & 128 & 250 & 55,6 & 7,4 \\
\hline $\mathrm{Nd}$ & 221 & 250 & 173 & 484 & 808 & 196 & 31 \\
\hline $\mathrm{Sm}$ & 54,3 & 61,9 & 40,0 & 107 & $\begin{array}{l}187 \\
\end{array}$ & 36,3 & 7,5 \\
\hline $\mathrm{Eu}$ & 2,6 & 2,5 & 1,9 & 4,2 & 8,4 & 2,1 & 1,4 \\
\hline $\mathrm{Gd}$ & 52,7 & 51,3 & 31,8 & 78,4 & 118 & 33,7 & 6,8 \\
\hline $\mathrm{Tb}$ & 9,5 & 9,0 & 4,8 & 11,1 & 17,4 & 4,5 & 1,1 \\
\hline Dy & 54,0 & 56,0 & 27,9 & 54,7 & 88,0 & 26,2 & 5,0 \\
\hline Ho & 10,5 & 9,4 & 4,3 & 7,1 & 12,8 & 5,0 & 1,3 \\
\hline $\mathrm{Er}$ & 30,9 & 31,0 & 12,4 & 18,6 & 32,4 & 15,7 & 3,1 \\
\hline $\mathrm{Tm}$ & 4,1 & 4,3 & 1,7 & 2,1 & 4,6 & 2,4 & 0,3 \\
\hline $\mathrm{Yb}$ & 28,5 & 32,1 & 11,8 & 13,5 & 26,5 & 16,0 & 4,0 \\
\hline $\mathrm{Lu}$ & 3,9 & 3,9 & 1,5 & 1,5 & 3,1 & 2,38 & 0,9 \\
\hline $\mathrm{Hf}$ & 4,3 & 9,1 & 4,2 & 4,1 & 5,4 & 8,5 & 3,9 \\
\hline $\mathrm{Ta}$ & 2,9 & 7,2 & 2,0 & 3,5 & 2,1 & 4,3 & 3,6 \\
\hline $\mathrm{W}$ & 17,4 & 11,1 & 5,9 & 11,4 & 15,3 & 20,8 & 2,2 \\
\hline $\mathrm{Tl}$ & 3,5 & 2,5 & 3,5 & 2,6 & Н.д. & 1,9 & 1,9 \\
\hline $\mathrm{Pb}$ & 35,1 & 44,6 & 41,1 & 39,6 & 94,5 & 105 & 18 \\
\hline Th & 38,8 & 60,2 & 67,4 & 118 & 52,6 & 64,1 & 18 \\
\hline $\mathrm{U}$ & 10,5 & 19,5 & 13,1 & 10,0 & 37,6 & 25,9 & 3,9 \\
\hline$\sum \mathrm{REE}$ & 2089 & 1444 & 890 & 2755 & 36 & 698 & 19 \\
\hline
\end{tabular}

Примечание: *-по [27]; Н.д. - нет данных

Note: *-according to [27]; H.d. - no data

Угленосные отложения. Угленосная толща эоценолигоценового возраста сложена серыми, зеленоватосерыми аргиллитами, алевролитами и песчаниками. Кроме того, в разрезе присутствуют мощные горизонты белых кварцевых песков и отдельные линзы гравелитов. В составе толщи на границе угленосных и надугольных отложений имеется горизонт туфов. Его возраст определен U-Pb методом (SHRIMP-II, АЦ ВСЕГЕИ) как поздний олигоцен $(25 \pm 0,2$ млн лет). Изотопный возраст 
надугольных туфов хорошо согласуется с современными палеонтологическими данными [19, 29]

На месторождении выделяют от 4 до 7 угольных пластов следующей номенклатуры: Первый нижний (Ін), Первый верхний (Ів), Второй нижний (ІІн), Второй верхний (IIв), Третий нижний (III), Третий верхний (IIIв) и Четвертый (IVH). Угольные пласты верхней части разреза имеют малые мощности и в основном простое строение (рис. 2). Пласт Первый на большей части месторождения слитный, но в северовосточной части разделяется на две части. Нижний пласт распространен только в северо-восточной части и выклинивается в районе центрального поднятия.

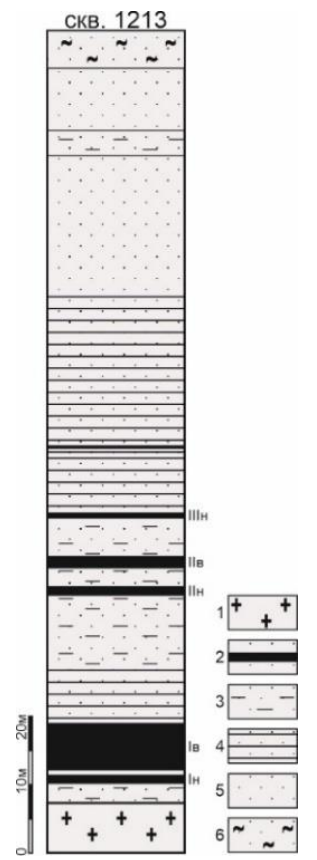

Pис. 2. Геологический разрез угленосных отложений по скважине 1213 на месторождении Спечугли (по [30]): 1 - граниты, 2 - пласты угля, 3 - алевролиты, 4 - песчаники, 5 -песок, 6 - глина

Fig. 2. Geological section of the coal-bearing deposits in the well 1213 in the Spetsugli deposit (according to [30]): 1 - granites, 2 - coal seams, 3 - siltstones, 4 - sandstones, 5 - sand, 6 - clay

Отработка месторождения показала, что все металлоносные угольные пласты в районе центрального поднятия на месторождении Спецугли имеют «эрозионные окна». Фактически это возвышенный участок суши в палеоболоте-палеоозере в период накопления угленосных отложений. Согласно результатам разведочного бурения, нижний пласт имеет несколько таких «окон», привязанных к другим более мелким поднятиям [30].

Угли месторождения представлены бурыми гумусовыми углями марки 2Б [31]. Угли плотные, буровато-черного цвета, матовые, полуматовые, реже полублестящие. Средний показатель отражения витринита 0,39\%. Согласно ГОСТ 25543-2013, они относятся к марке Б (бурые), группе 2Б, подгруппе 2БВ (второй бурый витринитовый) [32]. Угли месторождения среднезольные $\left(\mathrm{A}^{\mathrm{d}}=20 \%\right)$, с высоким выходом лету- чих веществ (59 \%), малосернистые $(0,4 \%)$, среднекалорийные $(27,1$ МДж/кг). Максимальная влагоемкость по пластопересечениям - от 23 до 48\%. Содержание гуминовых кислот в сухой беззольной массе от 9 до $70 \%$, в среднем - $28 \%$ [32].

\section{Методика исследования}

Исследование включало изучение вскрытого разрезом участка в центральной части германий-угольного месторождения, дополнительное опробование угольных пластов, углевмещающих пород, пород фундамента, подземных и поверхностных вод и их исследование современными аналитическими методами.

В 2018-2020 гг. выполнено детальное картирование и опробование разреза в нескольких сечениях. По каждому доступному для опробования угольному пласту в каждом сечении отобрано от 3 до 5 проб угля, а также пробы углевмещающих пород и внутрипластовых породных прослоев. На вскрытом в процессе отработки месторождения фундаменте изучено его строение, опробована кора выветривания гранитов, дайки андезитов и останец грейзенизированного гранита. Всего отобрано 80 проб угля и углевмещающих пород. Кроме того, опробованы поверхностные и дренажные воды из угольных пластов и из отстойника непосредственно в пределах разреза (10 проб). Схема опробования разреза приведена на рис. 3 .

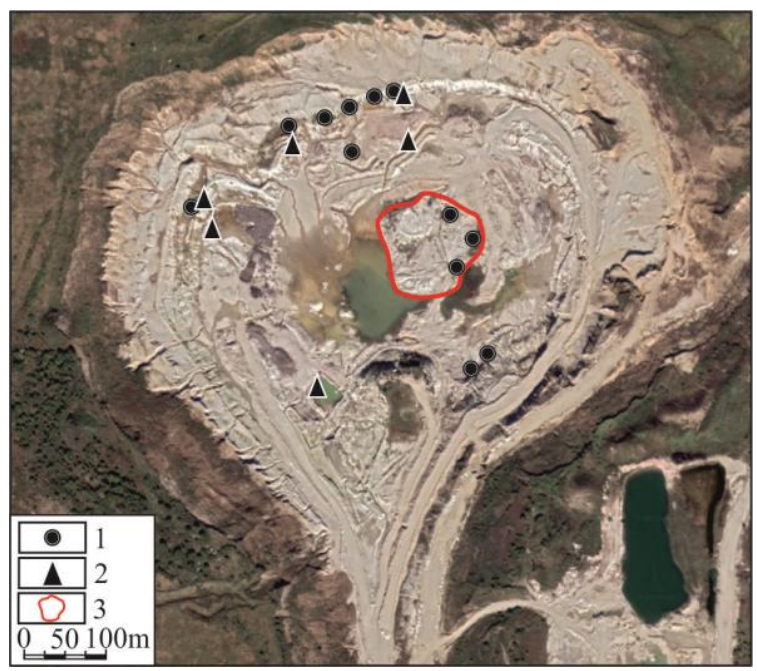

Pис. 3. Схема опробования углей, вмещаюющих пород и воды на угольном разрезе. (Источник фото Google maps). 1 - участки опробования углей, углевмещающих пород и пород фундамента; 2 места опробования вод; 3 - контур поверхности гранитного выступа

Fig. 3. Scheme of the sampling, host rocks and water in the coal mine. (Photo source - Google maps). 1 - coal sampling areas, coal-bearing rocks and foundation rocks; 2 - water sampling areas; 3 - surface contour of the granite ledge

Для сравнения небольшой объем опробования (27 проб) выполнен для угольных пластов, примыкающих к гранитному фундаменту, и самого фундамента на участке «Павловский-2», расположенном в 1,5-2,0 км северо-восточнее месторождения Спецугли. 
Исследование вещественного состава выполнено с применением комплекса современных аналитических методов. Состав элементов-примесей изучен методом масс-спектрометрии с индуктивно связанной плазмой на спектрометре Agilent 7700x (Agilent Techn., США) в лаборатории аналитической химии Центра коллективного пользования ДВГИ ДВО РАН (г. Владивосток). Содержание элементов в углях определялось с использованием двух методов пробоподготовки: с предварительным озолением и без озоления с химическим разложением [33]. Прямое определение в углях без предварительного озоления позволяет с высоким качеством определять содержание $\mathrm{Ge}, \mathrm{As}, \mathrm{Sb}, \mathrm{Tl}$ и других летучих элементов. Содержание 29 элементов параллельно оценивалось также методом ИНАА. Анализ выполнен в ядерно-геохимической лаборатории МИНОЦ «Урановая геология» ТПУ (г. Томск).

Содержание ртути определено методом атомноабсорбционного анализа на спектрометре PA-915+ с использованием пакета программ RA915P (ПНД Ф 16.1:2.23-2000). Пробы анализировали с помощью пиролитической приставки ПИРО-915 (метод пиролиза).

Минеральный состав углей и горных пород изучался методами оптической микроскопии и рентгенофазовым анализом. Рентгенофазовый анализ проводился на рентгеновском дифрактометре Bruker D2 Phaser c реализацией съемки рентгенограмм в геометрии Брегга-Брентано. Минимальная объемная доля определяемого минерала - 1 \%. Для расшифровки рентгенограмм применяются программные пакеты Eva и TOPAS на основе баз данных рентгеновской порошковой дифрактометрии PDF2 Международного центра дифракционных данных (ICDD, Denver, USA).

Микроминеральные фазы исследованы на сканирующем электронном микроскопе «Hitachi S-3400N» с приставкой для количественного элементного анализа «Bruker». Эта методика позволяет идентифицировать и фотографировать минеральные формы микронной и нанометровой размерности, определять их элементный состав.

Выполнен корреляционный анализ методом ранговой корреляции Спирмена. Выбранный комплекс аналитических методов позволяет выполнить полный комплекс исследований вещественного состава углей и горных пород.

\section{Геохимические особенности германиеносных углей и углевмещающих пород}

В месторождении Спецугли, как и в большинстве известных германий-угольных месторождений, наряду с Ge еще полвека назад установлено аномально высокое содержание $\mathrm{W}$ и $\mathrm{Be}$ [10]. Позднее появилась информация об обогащении углей $\mathrm{As}$ и $\mathrm{Sb}$ [11]. При этом в наиболее ранних работах конкретных данных о содержании и распределении этих элементов в угленосных отложениях не сообщалось, а сами выводы базировались на результатах приближенноколичественного анализа. Уже в XXI в. в процессе ревизионного опробования углей месторождения установлены аномальные содержания в них Rb, Cs, U,
Th и REE $[17,34,35]$, а также In, Sr, Ga, Zn, Cu, Ag, Tl и Мо [36].

С целью уточнения состава попутных элементов в рудах месторождения, изучения их ассоциаций и природы накопления было выполнено детальное опробование доступных для исследования верхних германийсодержащих угольных пластов (ІІн, ІІв и ІІІн) в нескольких сечениях во вскрытой части разреза. Как видно из табл. 3, все угольные пласты характеризуются близким спектром основных элементовпримесей.

В целом для металлоносных углей месторождения характерны аномально высокие, превышающие в десятки и даже сотни раз средние содержания для бурых углей мира, концентрации $\mathrm{Ge}, \mathrm{Sb}, \mathrm{Hg}, \mathrm{W}, \mathrm{Li}, \mathrm{Be}$, $\mathrm{Cs}$, и As. Несколько менее аномальны уровни накопления U, Mo, Y, Rb, средних и тяжелых лантаноидов, $\mathrm{Zn}$ и $\mathrm{Ga}$.

Германий. Для изученных сечений исследуемого участка месторождения характерно экстремально высокое содержание $\mathrm{Ge}$, превышающее средние оценки для пластов по данным разведочных работ и более поздние оценки по ограниченному количеству проб $[7,8,14]$. В целом они близки к опубликованной средней оценке по единичному сечению [16]. При этом подтвердилась тенденция, выраженная в снижении среднего содержания в пластах снизу вверх по разрезу [8]. Следует отметить, что эта тенденция не столь очевидна. Согласно другим данным, наоборот, содержание увеличивается снизу вверх $[14,16]$. К тому же нужно учесть, что нами не опробован пласт I, залегающий в нижней части разреза.

Корреляционный анализ, выполненный методом ранговой корреляции Спирмена, показал значимую положительную связь Ge c рассматриваемой группой элементов-спутников. Наиболее высокие коэффициенты корреляции у $\mathrm{Ge} \mathrm{c} \mathrm{Sb}(\mathrm{r}=0,91), \mathrm{Hg}(\mathrm{r}=0,72)$, As $(\mathrm{r}=0,61), \mathrm{Mo}(\mathrm{r}=0,62), \mathrm{W}(\mathrm{r}=0,64), \mathrm{U}(\mathrm{r}=0,67), \mathrm{Tl}(\mathrm{r}=0,59)$ и $\mathrm{Na}(\mathrm{r}=0,79)$. Положительная невысокая, но значимая, выше критического значения, связь установлена для $\mathrm{Li}$ $(\mathrm{r}=0,39), \mathrm{Be}(\mathrm{r}=0,50), \mathrm{Cs}(\mathrm{r}=0,39), \mathrm{Ga}(\mathrm{r}=0,46), \mathrm{Y}(\mathrm{r}=0,37)$ и тяжелых лантаноидов (HREE) $(\mathrm{r}=0,39-0,40)$. При этом у большей части этих элементов отмечена положительная корреляция с зольностью. Этот факт связывает $\mathrm{Ge}$ с источником поступления данных элементов в угольный пласт, в качестве которого в данном случае выступают грейзенизированные граниты. Отрицательная корреляция с зольностью отмечена лишь только для $\mathrm{W}$, а отсутствие корреляции (незначимая связь) - у $\mathrm{Ge}, \mathrm{As}, \mathrm{Se}, \mathrm{Be}, \mathrm{Y}, \mathrm{Mo} \mathrm{и} \mathrm{средних} \mathrm{лантаноидов} \mathrm{(MREE).}$ Это свидетельствует о преимущественно аквагенном поступлении элементов в угольный пласт.

Распределение германия в месторождении. Выполненная в конце 60-х гг. ХХ в. оценка кондиционных запасов Ge показала, что 75,3 \% их сосредоточены в пласте I при среднем содержании 348 г/т угля [30]. Это свидетельствует о том, что основное поступление металла происходило на ранних стадиях накопления угленосной толщи, либо разгрузка германиеносных вод шла преимущественно в нижней части угленосного разреза. 
Таблица 3. Среднее содержание основных элементовпримесей в углях германиеносных пластов месторождения Спеиугли, г/m

Table 3. Average content of main trace elements in germaniferous coal sems of the Spetsugli deposit, ppm

\begin{tabular}{|c|c|c|c|c|c|}
\hline \multirow{2}{*}{ 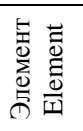 } & \multicolumn{3}{|c|}{ Пласт/Seam } & \multirow{2}{*}{$\begin{array}{c}\text { Среднее для } \\
\text { разреза } \\
\text { Average for the } \\
\text { section } \\
\end{array}$} & \multirow{2}{*}{$\begin{array}{c}\text { Кларк для угля* } \\
\text { Mean for the coals } \\
\text { of the world* }\end{array}$} \\
\hline & ІІн & ІІв & ІІІн & & \\
\hline $\mathrm{Li}$ & 27,9 & 113 & 172 & 105 & $10 \pm 1$ \\
\hline $\mathrm{Be}$ & 50,2 & 55,6 & 57,0 & 54,4 & $1,2 \pm 0,1$ \\
\hline $\mathrm{Sc}$ & 5,1 & 6,6 & 3,5 & 5,3 & $4,1 \pm 0,2$ \\
\hline $\mathrm{V}$ & 40,6 & 63,4 & 22,7 & 45,3 & $22 \pm 2$ \\
\hline $\mathrm{Cr}$ & 19,7 & 24,4 & 11,6 & 19,4 & $15 \pm 1$ \\
\hline Co & 7,6 & 12,9 & 8,0 & 10,0 & $4,2 \pm 0,3$ \\
\hline $\mathrm{Ni}$ & 11,8 & 22,7 & 12,8 & 16,8 & $9,0 \pm 0,9$ \\
\hline $\mathrm{Cu}$ & 12,6 & 35,7 & 12,5 & 22,4 & $15 \pm 1$ \\
\hline $\mathrm{Zn}$ & 17,0 & 99,9 & 57,9 & 64,2 & $18 \pm 1$ \\
\hline $\mathrm{Ga}$ & 27,3 & 10,2 & 8,1 & 14,5 & $5,5 \pm 0,3$ \\
\hline $\mathrm{Ge}$ & 1676 & 1016 & 1173 & 1249 & $2,0 \pm 0,1$ \\
\hline As & 26,6 & 189 & 238 & 157 & $7,6 \pm 1,3$ \\
\hline $\mathrm{Se}$ & 1,7 & 2,6 & 3,5 & 2,6 & $1,0 \pm 0,15$ \\
\hline $\mathrm{Rb}$ & 71,6 & 31,7 & 30,7 & 42,8 & $10 \pm 0,9$ \\
\hline $\mathrm{Sr}$ & 116 & 79,2 & 103 & 96,5 & $120 \pm 10$ \\
\hline $\mathrm{Y}$ & 81,1 & 55,1 & 108,7 & 77,8 & $8,6 \pm 0,4$ \\
\hline $\mathrm{Zr}$ & 98,5 & 70,7 & 55,1 & 74,2 & $35 \pm 2$ \\
\hline $\mathrm{Nb}$ & 6,4 & 5,2 & 4,1 & 5,2 & $3,3 \pm 0,3$ \\
\hline Mo & 5,9 & 7,8 & 6,2 & 6,8 & $2,2 \pm 0,2$ \\
\hline $\mathrm{Ag}$ & 0,08 & 0,19 & 0,08 & 0,13 & $0,09 \pm 0,02$ \\
\hline $\mathrm{Cd}$ & 0,26 & 0,97 & 0,25 & 0,56 & $0,24 \pm 0,04$ \\
\hline $\mathrm{Sn}$ & 1,4 & 1,4 & 1,1 & 1,3 & $0,79 \pm 0,09$ \\
\hline $\mathrm{Sb}$ & 698 & 164 & 148 & 312 & $0,84 \pm 0,09$ \\
\hline Cs & 72,7 & 26,0 & 18,2 & 37,1 & $0,98 \pm 0,1$ \\
\hline $\mathrm{Ba}$ & 281 & 183 & 175 & 209 & $150 \pm 20$ \\
\hline $\mathrm{La}$ & 14,0 & 24,0 & 17,2 & 19,2 & $10 \pm 0,5$ \\
\hline $\mathrm{Ce}$ & 26,8 & 45,3 & 41,8 & 39,0 & $22 \pm 1$ \\
\hline $\operatorname{Pr}$ & 3,4 & 5,5 & 6,1 & 5,1 & $3,5 \pm 0,3$ \\
\hline $\mathrm{Nd}$ & 13,9 & 21,6 & 29,4 & 21,7 & $11 \pm 1$ \\
\hline Sm & 3,9 & 4,8 & 9,7 & 5,9 & $1,9 \pm 0,1$ \\
\hline $\mathrm{Eu}$ & 0,9 & 0,9 & 2,0 & 1,2 & $0,50 \pm 0,02$ \\
\hline $\mathrm{Gd}$ & 7,0 & 6,2 & 12,6 & 8,3 & $2,6 \pm 0,2$ \\
\hline $\mathrm{Tb}$ & 1,3 & 1,1 & 2,2 & 1,5 & $0,32 \pm 0,03$ \\
\hline Dy & 10,1 & 7,2 & 15,2 & 10,3 & $2,0 \pm 0,1$ \\
\hline Ho & 2,3 & 1,6 & 3,5 & 2,3 & $0,50 \pm 0,05$ \\
\hline $\mathrm{Er}$ & 6,8 & 4,4 & 11,1 & 7,0 & $0,85 \pm 0,08$ \\
\hline $\mathrm{Tm}$ & 1,0 & 0,6 & 1,8 & 1,1 & $0,31 \pm 0,02$ \\
\hline $\mathrm{Yb}$ & 5,8 & 3,6 & 11,0 & 6,4 & $1,0 \pm 0,05$ \\
\hline $\mathrm{Lu}$ & 0,9 & 0,5 & 1,8 & 1,0 & $0,19 \pm 0,02$ \\
\hline $\mathrm{Hf}$ & 2,4 & 1,8 & 1,5 & 1,9 & $1,2 \pm 0,1$ \\
\hline $\mathrm{Ta}$ & 0,4 & 0,3 & 0,3 & 0,35 & $0,26 \pm 0,03$ \\
\hline $\mathrm{W}$ & 276 & 239 & 246 & 252 & $1,2 \pm 0,2$ \\
\hline $\mathrm{Hg}$ & 0,78 & 3,01 & 3,37 & 2,47 & $0,10 \pm 0,01$ \\
\hline $\mathrm{Tl}$ & 0,6 & 0,6 & 0,5 & 0,5 & $0,68 \pm 0,07$ \\
\hline $\mathrm{Pb}$ & 7,0 & 17,6 & 8,3 & 11,9 & $6,6 \pm 0,4$ \\
\hline Th & 4,8 & 9,5 & 6,6 & 7,3 & $3,3 \pm 0,2$ \\
\hline $\mathrm{U}$ & 15,8 & 11,7 & 10,3 & 12,5 & $2,9 \pm 0,3$ \\
\hline ¿REE & 98,1 & 127,3 & 165,4 & 130,0 & 56,7 \\
\hline $\mathrm{A}^{\mathrm{d},} \%$ & 39,9 & 28,5 & 25,3 & 30,8 & \\
\hline
\end{tabular}

Примечание: *-по [37]; $A^{d}-$ зольность.

Note: *-according to [37]; $A^{d}$ - ash yield.

Другой важной особенностью распределения Ge по площади является субизометричная форма рудных тел. Рельеф фундамента в пределах месторождения на относительно локальном участке сильно изрезанный: мощность осадочных отложений колеблется от 320 до 42 м. В центре металлоносной площади находится наиболее высокое поднятие, формирующее «эрози- онное окно» в угольных пластах. Площадное распределение $\mathrm{Ge}$ в угольных пластах имеет субизометричную концентрически-зональную форму вокруг этого выступа гранитного фундамента $[7,8,11,30,38]$. Характер распределения Ge по площади в пределах каждого пласта таков, что предполагает площадное поступление металла в угольный пласт по всему ореолу вокруг возвышенности (рис. 1). Такие формы рудных тел и ореолов $\mathrm{Ge}$ в угольных пластах в пределах месторождения позволяют заключить, что источник поступления $\mathrm{Ge}, \mathrm{W}, \mathrm{Sb}$ и других элементовспутников находился в пределах куполовидного поднятия. При этом источник имел площадной, а не линейный характер, так как металлом обогащены угольные пласты непосредственно вокруг возвышенных участков фундамента с максимумом в пределах центрального выступа (рис. 1). Линейные зоны разгрузки, которые могли бы быть связаны с подновлением тектонических нарушений в зонах понижений рельефа $[9,11,14,17]$, на исследуемом участке отсутствуют. К тому же они не могут обеспечить такую форму рудных тел. Степень контрастности оруденения в углях в пределах рудного тела различна, что может быть обусловлено как неравномерностью распределения металлов в источнике, так и неравномерным переносом вещества водами в локальных участках.

Промышленная германиеносность во всех пластах имеет близкие контуры распространения в пространстве. Металлоносные участки в пластах расположены друг над другом, создавая ярусное строение месторождения. Площадные размеры металлоносных участков пластов сокращаются снизу вверх от 550 тыс. м² для пласта I до 250 тыс. м² для пласта IIIн $[14,30]$. Все металлоносные угли отчетливо тяготеют к наиболее контрастному поднятию в центре площади. При этом в пределах площади имеется несколько самостоятельных ореолов, приуроченных к другим поднятиям, но не имеющим промышленного значения из-за сравнительно невысокого содержания $\mathrm{Ge}$. Характерно наличие во всех пластах с промышленным оруденением вплоть до ІІІн «эрозионных окон», представленных элювиальной корой выветривания гранитов. Пласты в пределах месторождения без таких «окон» не имеют промышленного оруденения, хотя и отличаются повышенным содержанием $\mathrm{Ge}$ (15 г/т для IIІв и 11 г/т для IV) [30].

Важной характеристикой рудоносной площади является и более существенное обогащение углевмещающих пород междупластий по сравнению с породами за пределами месторождения. Если за пределами месторождения содержание $\mathrm{Ge}$ в аргиллитах, алевролитах и песчаниках изменяется в интервале $1-3$ г/T, то в границах месторождения от 4 до 156 г/т. При этом минимальные содержания приходятся на более грубозернистые осадки.

$\mathrm{B}$ вертикальном профиле угольного пласта $\mathrm{Ge}$ распределен неоднотипно. На участках с невысоким содержанием $(<50$ г/T) его распределение либо подчиняется «закону Зильберминца» с обогащением приконтактовых зон пласта, либо, чаще, его содержа- 
ние последовательно уменьшается от приподошвенной к прикровельной зоне. В металлоносных углях ранее было отмечено обогащение центральной зоны пласта [7, 21]. Для золы угля в изученных нами сечениях с промышленной германиеносностью имеет место обогащение в центральной части угольного пласта для пластов ІІв и ІІн и последовательное увеличение содержания $\mathrm{Ge}$ от подошвы к кровле для пласта IIIн. Для золы угля в пределах отдельных сечений отчетливо просматривается отрицательная корреляция содержания Ge с зольностью.

\section{Элементы-спутники германиевого оруденения}

Как следует из средних оценок по пластам на исследуемом участке (табл. 3), для германиеносных углей месторождения характерно аномальное, превышающее в десятки и даже сотни раз среднее содержание для бурых углей мира, содержание $\mathrm{Ge}, \mathrm{Li}, \mathrm{Be}, \mathrm{Cs}, \mathrm{As}$, $\mathrm{Sb}, \mathrm{Hg}$ и W. Несколько менее аномальны уровни накопления U, Mo, Y, Rb, средних и тяжелых лантаноидов, $\mathrm{Zn}$ и $\mathrm{Ga}$. Спектр сопутствующих элементов достаточно обширен и включает ассоциации, формирование которых в эндогенных условиях может быть обусловлено только разными процессами. Эндогенное оруденение такого типа должно быть полигеннымполихронным. Однако в гипергенезе их накопление может быть обусловлено единым процессом. В разрезе угленосных отложений отмечено последовательное снижение содержания от нижних пластов к верхним для $\mathrm{Ge}, \mathrm{Ga}, \mathrm{Rb}, \mathrm{Nb}, \mathrm{Zr}, \mathrm{Sn}, \mathrm{Sb}, \mathrm{Cs}, \mathrm{Ba}, \mathrm{Hf}, \mathrm{Ta}, \mathrm{W}, \mathrm{Tl}, \mathrm{U}$ и Th одновременно с уменьшением зольности. Вверх по разрезу отчетливо растет содержание $\mathrm{Li}, \mathrm{Be}, \mathrm{As}, \mathrm{Se}, \mathrm{Hg}$, средних и тяжелых лантаноидов. Для золы угля тенденции несколько отличаются. Здесь отмечен отчетливый рост содержания снизу вверх $\mathrm{Li}, \mathrm{Be}, \mathrm{As}, \mathrm{Se}, \mathrm{Sr}, \mathrm{Y}$, $\mathrm{W}, \mathrm{Hg}, \mathrm{Tl}$ и лантаноидов. Содержание $\mathrm{Ga}, \mathrm{Sb}, \mathrm{Cs}$ отчетливо снижается. Тенденции изменения содержания других элементов в разрезе неоднозначны.

Редкие щелочи ( $L i, R b, C s)$. Обогащенность германиеносных углей месторождения Спецугли редкими щелочами ( $\mathrm{Rb}$ и $\mathrm{Cs}$ ) детально исследована на примере одной скважины В.В. Серединым [34]. К этим данным можно добавить такое же аномальное накопление здесь лития (табл. 3). Корреляционный анализ показал высокую (r=0,76-0,87) корреляционную связь содержания этих элементов в углях с зольностью. С другой стороны, они также связаны высокими корреляционными связями между собой и с основными породообразующими щелочными элементами (K и $\mathrm{Na})$. Особенно высок уровень связи с калием. Для $\mathrm{Rb}$ коэффициент ранговой корреляции с $\mathrm{K}_{2} \mathrm{O}$ составляет 0,98 , для Cs - 0,88, для $\mathrm{Li}-0,64$. Высокие коэффициенты корреляции $(\mathrm{r}=0,7-0,9)$ установлены для этих элементов с $\mathrm{SiO}_{2}$ и $\mathrm{Al}_{2} \mathrm{O}_{3}$. Это обстоятельство позволяет рассматривать в качестве основного источника $\mathrm{Li}, \mathrm{Rb}$ и Cs слюды, а также микроклин, широко распространенные в составе грейзенизированных гранитов вознесенского комплекса. Подтверждение тому результаты анализа монофракции «биотита», отобранного из останца грейзенизированного гранита на месторождении «Спецугли» (табл. 4).
Таблица 4. Микроэлементный состав монофракции биотита, $2 / m$

Table 4. Trace element composition of the biotite monofraction, ppm

\begin{tabular}{|c|c|c|c|c|c|}
\hline $\begin{array}{c}\text { Элемент } \\
\text { Element }\end{array}$ & $\begin{array}{c}\text { Содержа- } \\
\text { ние } \\
\text { Content }\end{array}$ & $\begin{array}{c}\text { Элемент } \\
\text { Element }\end{array}$ & $\begin{array}{c}\text { Содержа- } \\
\text { ние } \\
\text { Content }\end{array}$ & $\begin{array}{c}\text { Элемент } \\
\text { Element }\end{array}$ & $\begin{array}{c}\text { Содержа- } \\
\text { ние } \\
\text { Content }\end{array}$ \\
\hline $\mathrm{Li}$ & 483 & $\mathrm{Zr}$ & 1089 & $\mathrm{Gd}$ & 503 \\
\hline $\mathrm{Be}$ & 14,0 & $\mathrm{Nb}$ & 460 & $\mathrm{~Tb}$ & 84,9 \\
\hline $\mathrm{Sc}$ & 147 & $\mathrm{Mo}$ & 14,6 & $\mathrm{Dy}$ & 430 \\
\hline $\mathrm{V}$ & 125 & $\mathrm{Ag}$ & 2,0 & $\mathrm{Ho}$ & 78,8 \\
\hline $\mathrm{Cr}$ & 21,0 & $\mathrm{Cd}$ & 1,6 & $\mathrm{Er}$ & 214 \\
\hline $\mathrm{Co}$ & 131 & $\mathrm{Sn}$ & 86,0 & $\mathrm{Yb}$ & 201 \\
\hline $\mathrm{Ni}$ & 21,8 & $\mathrm{Sb}$ & 96,1 & $\mathrm{Lu}$ & 31,1 \\
\hline $\mathrm{Cu}$ & 15,3 & $\mathrm{Te}$ & 0,14 & $\mathrm{Hf}$ & 40,8 \\
\hline $\mathrm{Zn}$ & 662 & $\mathrm{Cs}$ & 104 & $\mathrm{Ta}$ & 20,2 \\
\hline $\mathrm{Ga}$ & 162 & $\mathrm{Ba}$ & 311 & $\mathrm{~W}$ & 493 \\
\hline $\mathrm{Ge}$ & 12,8 & $\mathrm{La}$ & 4111 & $\mathrm{Re}$ & 0,023 \\
\hline $\mathrm{As}$ & 385 & $\mathrm{Ce}$ & 7253 & $\mathrm{Tl}$ & 45,8 \\
\hline $\mathrm{Se}$ & 77,5 & $\mathrm{Pr}$ & 937 & $\mathrm{~Pb}$ & 758 \\
\hline $\mathrm{Rb}$ & 2189 & $\mathrm{Nd}$ & 2992 & $\mathrm{Th}$ & 203 \\
\hline $\mathrm{Sr}$ & 94,9 & $\mathrm{Sm}$ & 695 & $\mathrm{U}$ & 670 \\
\hline $\mathrm{Y}$ & 2568 & $\mathrm{Eu}$ & 32,9 & $\mathrm{EP} 3 \ni$ & 17564 \\
\hline
\end{tabular}

Название монофракции условно, так как в ней представлен как собственно биотит, так и новообразованные развитые по нему минеральные фазы: хлорит, мусковит и др. Как видно из этих данных, слюдистый агрегат чрезвычайно богат $\mathrm{Rb}(0,22 \%)$, существенно обогащен Li (483 г/т) и Cs $(104$ г/т) и вполне может рассматриваться в качестве основного источника редких щелочей в германиеносных углях. Кроме того, значительная часть этих элементов может быть связана с полевыми шпатами и альбитом [34]. Полное или существенное разложение этих минералов насыщает растворы редкими щелочами и является источником сорбционного накопления Rb, Cs и Li в органическом веществе угля и на глинах.

Исследование форм нахождения показывает, что 62-66 \% Rb и Li связаны с минеральным веществом угля, а примерно 1/3 связана с органическим веществом либо сорбирована на глинистом веществе. У Cs доля минеральной фазы несколько меньше, а у органической больше, но все же с отчетливым преобладанием Cs минерального. Второстепенное значение водорастворимых форм в обогащении углей редкими щелочами подтверждается и фактом низкого их содержания в угольных включениях (табл. 5).

При этом углефицированные древесные включения в песчаниках вблизи выхода фундамента несколько обогащены Li и Cs по сравнению с их аналогами на удалении от него. Это подтверждает важную роль гранитного выступа в накоплении в углях не только германия, но и других сопутствующих ему элементов. Углевмещающие породы вблизи гранитного выступа на месторождении Спецугли существенно богаче $\mathrm{Rb}$ и $\mathrm{Cs}$ по сравнению с таковыми на удаленном от него на 1,5 км угольном разрезе «Павловский 2». Это указывает, в первую очередь, на специфику состава области сноса и формирования этих отложений. Как отмечено, область сноса на месторождении Спецугли представлена калишпатизированными и грейзенизированными гранитами. Пласт IIIн, кроме того, аномально обогащен Li наряду с Y и 
лантаноидами. Природа этого обогащения может быть связана с современными кислыми сульфатными водами, дренирующими через этот пласт. Эти воды аномально обогащены Li, Y, P3Э, Ge, Co, Ni, Zn, Rb, $\mathrm{Cs}, \mathrm{Sr}, \mathrm{U}, \mathrm{Al}, \mathrm{Fe}$, и Mn. Формирование подобного типа кислых сульфатных вод, аномально обогащенных редкими щелочами, показано на примере разрушения W-Mо руд Забайкалья в зоне гипергенеза в настоящее время [39].

Таблица 5. Микроэлементный состав углефицированной древесины, $2 / m$

Table 5. $\quad$ Trace element composition of the carbonised wood, ppm

\begin{tabular}{|c|c|c|c|c|c|c|c|}
\hline 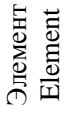 & 苚 & 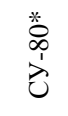 & 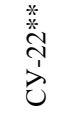 & 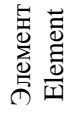 & 荅 & \begin{tabular}{l}
$*$ \\
\multirow{2}{*}{} \\
1 \\
1 \\
$ن$
\end{tabular} & 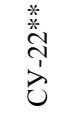 \\
\hline $\mathrm{Li}$ & 4,6 & 6,5 & 3,6 & $\mathrm{Cs}$ & 4,9 & 4,5 & 0,9 \\
\hline $\mathrm{Be}$ & 10,0 & 10,0 & 1,6 & $\mathrm{Ba}$ & 467 & 344 & 70 \\
\hline $\mathrm{Sc}$ & 1,70 & 0,69 & 3,1 & $\mathrm{La}$ & 3,3 & 2,2 & 6,7 \\
\hline $\mathrm{V}$ & 200 & 174 & 14,1 & $\mathrm{Ce}$ & 6,8 & 4,8 & 15,2 \\
\hline $\mathrm{Cr}$ & 27,4 & 25,5 & 42,1 & $\operatorname{Pr}$ & 0,86 & 0,63 & 1,66 \\
\hline Co & 2,5 & 2,2 & 25,8 & $\mathrm{Nd}$ & 3,7 & 2,9 & 6,0 \\
\hline $\mathrm{Ni}$ & 2,4 & 2,4 & 16,2 & $\mathrm{Sm}$ & 1,2 & 1,0 & 1,3 \\
\hline $\mathrm{Cu}$ & 3,8 & 0,27 & 12,5 & $\mathrm{Eu}$ & 0,26 & 0,24 & 0,26 \\
\hline $\mathrm{Zn}$ & 5,5 & 11,3 & 31,8 & $\mathrm{Gd}$ & 1,9 & 1,8 & 1,4 \\
\hline $\mathrm{Ga}$ & 11,1 & 9,1 & 2,6 & $\mathrm{~Tb}$ & 0,40 & 0,40 & 0,20 \\
\hline $\mathrm{Ge}$ & 5306 & 7210 & 32 & Dy & 3,3 & 3,4 & 1,3 \\
\hline As & 52 & 49 & 65 & Ho & 0,81 & 0,85 & 0,28 \\
\hline $\mathrm{Se}$ & 0,7 & 0,4 & 1,1 & $\mathrm{Er}$ & 2,51 & 2,86 & 0,78 \\
\hline $\mathrm{Rb}$ & 8,5 & 4,6 & 7,6 & $\mathrm{Tm}$ & 0,44 & 0,42 & 0,12 \\
\hline $\mathrm{Sr}$ & 135 & 152 & 19 & $\mathrm{Yb}$ & 3,2 & 3,4 & 0,77 \\
\hline $\mathrm{Y}$ & 18,5 & 15,3 & 7,8 & $\mathrm{Lu}$ & 0,47 & 0,52 & 0,11 \\
\hline $\mathrm{Zr}$ & 144 & 129 & 108 & $\mathrm{Hf}$ & 1,18 & 0,85 & 1,17 \\
\hline $\mathrm{Nb}$ & 42,3 & 39,9 & 4,1 & $\mathrm{Ta}$ & 0,08 & 0,04 & 0,18 \\
\hline Mo & 90,1 & 99,2 & 28,1 & $\mathrm{~W}$ & 489 & 724 & 3,1 \\
\hline $\mathrm{Ag}$ & 0,23 & 0,05 & 0,26 & $\mathrm{Tl}$ & 4,2 & 6,1 & 0,09 \\
\hline $\mathrm{Cd}$ & 0,16 & 0,27 & 0,29 & $\mathrm{~Pb}$ & 4,4 & 5,2 & 7,0 \\
\hline $\mathrm{Sn}$ & 0,57 & 0,15 & 1,5 & Th & 4,0 & 4,6 & 3,1 \\
\hline $\mathrm{Sb}$ & 2714 & 3269 & 30,0 & $\mathrm{U}$ & 26,5 & 38,0 & 1 \\
\hline
\end{tabular}

Примечание: * - пробы в песчаниках угленосной толщчи вблизи фундамента; ** - проба в песчаниках над угленосной толщей.

Note: * - samples in the sandstones of the coal seam near the foundation; ** - samples in the sandstones above the coal seam.

Лантаноиды $и$ иттрий. Германиеносные пласты существенно обогащены РЗЭ. Особенно аномальны они по содержанию Ү, концентрация которого в золе угля в среднем в изученном сечении превышает 250 г/т, а в пласте ІІІн составляет 430 г/т. В качестве источника, как и для группы редких щелочных элементов ( $\mathrm{Li}, \mathrm{Rb}$, $\mathrm{Cs})$, могут также рассматриваться грейзенизированные граниты фундамента, аномально обогащенные иттрием (табл. 2). В монофракции биотита из этих гранитов содержание Y превышает 0,25 \% (табл. 4). Их же можно рассматривать и как источник лантаноидов в углях. К схожему выводу пришел В.В. Середин [35], изучивший распределение РЗЭ по двум скважинам, вскрывшим весь угленосный разрез на месторождении Спецугли. Он предположил кластогенную природу фонового накопления РЗЭ в углях месторождения и эпигенетическое концентрирование тяжелых
РЗЭ и Y в связи с поздним плиоцен-четвертичным гидротермальным процессом.

Как показали настоящие исследования, роль водных растворов в накоплении как тяжелых, так и легких РЗЭ достаточно велика. Характер нормированных графиков (рис. 4) закономерный и не несет следы проявления двух или более равнозначных, но не взаимосвязанных процессов. К тому же, дайки, с которыми связывалось проявление гидротермальной деятельности после формирования угольных пластов [35], имеют не неоген-четвертичный, а позднепермский возраст, значительно более ранний, чем возраст угленакопления. Характер нормированных графиков не умаляет значения гранитов в накоплении как тяжелых, так и легких лантаноидов в углях. Граниты в фундаменте, подвергнутые кварц-полевошпатовому метасоматозу и грейзенизации, которые могут рассматриваться как основной источник РЗЭ в углях, отличаются аномально высокими содержаниями суммы лантаноидов (от 0,07 до 0,36 \%) и Ү (от 101 до 467 г/т) (табл. 2).

Аномальны по содержанию РЗЭ и дренирующие в настоящее время по германиеносным пластам водные растворы. Еще более аномальные содержания РЗЭ выявлены в современных кислых сульфатных водах зоны гипергенеза к востоку от исследуемой площади [40]. Одной из особенностей современных вод, дренирующих угольные пласты на месторождении, является наличие в них отрицательной Еu аномалии $\left(\mathrm{Eu} / \mathrm{Eu}^{*}=0,6-0,7\right)$, указывающей на связь этих водных растворов с кислыми магматическими породами (рис. $4, e$ ).

Изучены вертикальные разрезы угольных пластов в пределах рудоносной площади с аномально высоким содержание $\mathrm{Ge}$ и за ее пределами с околокларковым его содержанием. В германиеносных углях содержание РЗЭ в 1,5-2 раза выше. Однако из-за высокой зольности металлоносных углей золы оруденелых и безрудных разностей сопоставимы по содержанию как лантаноидов, так и иттрия. Лантан-иттербиевое отношение также отличается не существенно: в среднем 3,0 для германиеносных углей и 4,5 для углей с рядовым содержанием $\mathrm{Ge}$ вблизи рудного блока. Это позволяет говорить о едином источнике накопления Р3Э в углях в пределах исследуемого участка. Таковым, вероятно, является гидротермально измененный редкометалльный гранит выступа фундамента. При этом ведущая роль принадлежит не собственно гранитам, а наложенным на них гидротермально метасоматическим изменениям, связанным, по-видимому, с внедрением даек пермского возраста и последующим выветриванием. Роль этих процессов видна на примере углей из угледобывающего разреза «Павловский-2» в 1,5-2 км к северо-востоку от участка Спецугли (рис. 1). Здесь в углях, непосредственно налегающих на кору выветривания гранитов фундамента и обогащенных Ge на уровне 13-144 г/т, содержание суммы лантаноидов составляет 44-50 г/т, Y - 20-22 г/т. Непосредственно вблизи выветрелой дайки и над ней содержание суммы лантаноидов в перекрывающих углях составляет 61-214 г/т, Y - 46-361 г/т. Здесь же 
аномально и содержание $\mathrm{Ge}(27-125$ г/т), $\mathrm{Hg}$ (до 1,5 г/т), Мо (до 68 г/т) и W (22-63 г/т). Видна связь уровней накопления Р3Э в углях с дайковым комплексом. Кора выветривания по аналогичной дайке в Спецуглях также богаче РЗЭ, чем таковая по гранитам на удалении от нее. Содержание Ү в коре выветривания дайки и гранитов здесь составляет 236 и 178 г/т соответственно, а суммы лантаноидов - 682 и 208 г/т. Разница в содержании РЗЭ в гидротермально
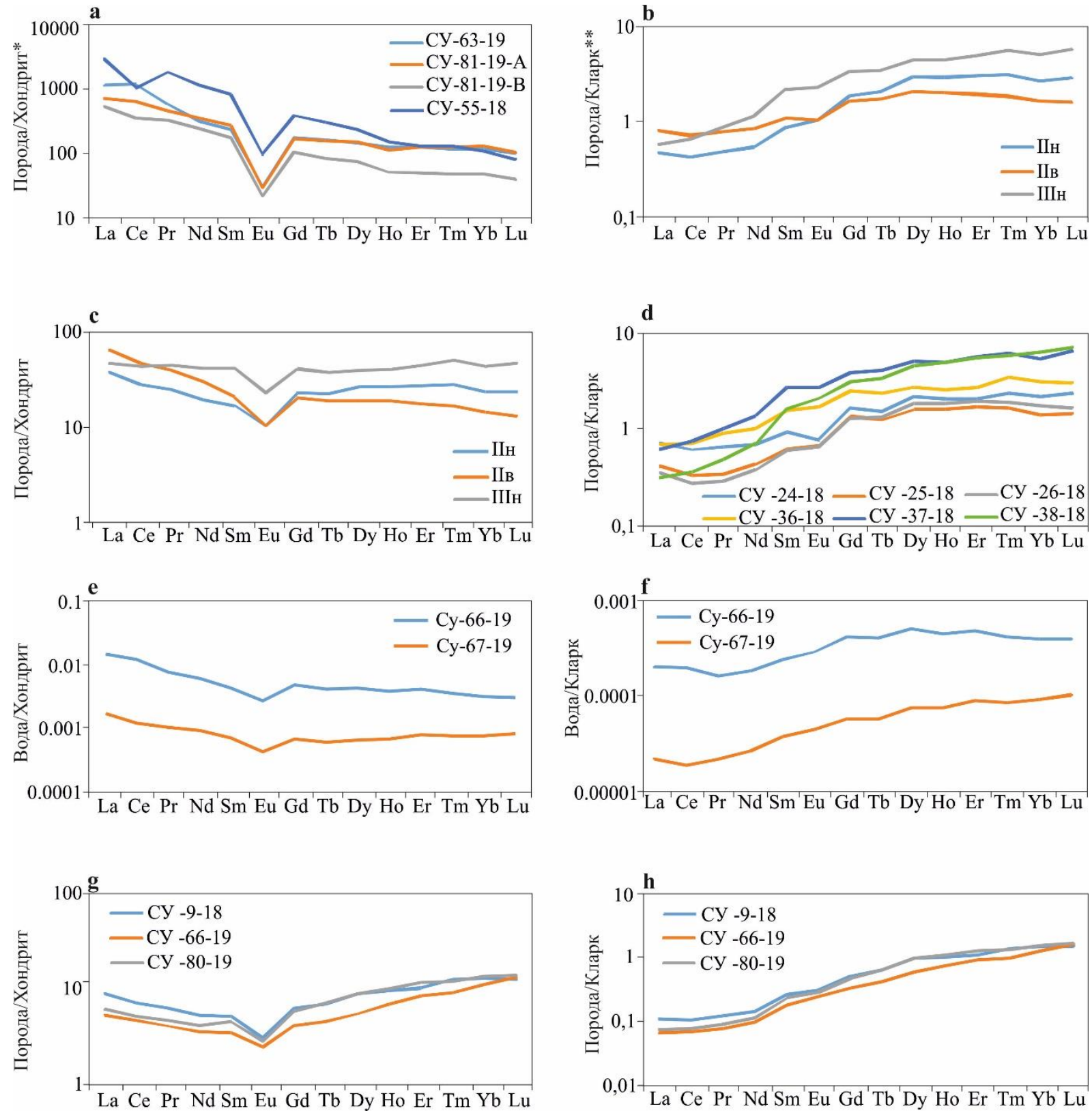

Pис. 4. Нормированные графики распределения РЗЭ в гранитах фундамента (a), угольных пластах (b, c), углях пласта IIIн (d), дренажных водах $(e, f)$ и углефицированной древесине $(g, h)$ месторождения Спеиугли. Примечание: *-нормировано на хондрит по [41]; **-нормировано на содержание в верхней континентальной коре no [41]

Fig. 4. Normalized graphs of REE distribution in the granites of the foundation (a), coal seams (b, c), coal seam IIIn (d), drainage water $(e, f)$ and carbonized wood $(g, h)$ of the Spetsugli deposit. Note:* normalized for chondrite according to [41]; **-normalized for the content in the upper continental crust according to [41] 
На поступление Р3Э в угольные пласты из коры выветривания гранитов указывает характер нормированных графиков распределения лантаноидов в углях (рис. $4, b, c)$. Здесь на обоих типах графиков и при нормировке на хондрит (рис. $4, c$ ), и при нормировке на средний состав верхней континентальной земной коры (рис. $4, b$ ) отчетливо просматривается Еu аномалия $\left(\mathrm{Eu} / \mathrm{Eu}^{*}=0,50-0,60\right)$, типичная для пород, связанных с гранитоидами. Одновременно имеет место слабо выраженная Се аномалия, которая характерна именно для зоны выветривания в результате окисления Се до валентности 4+ и удаления его в процессе миграции лантаноидов. При этом в результате выветривания гранитов отмечено появление как положительной, так и отрицательной аномалии Се (рис. $4, a$ ).

Характер графиков также указывает на преимущественно гидрогенную природу накопления РЗЭ в углях (рис. $4, b, d$ ). Здесь характерен Н-тип распределения РЗЭ, указывающий на водный механизм их накопления в угольном пласте [42]. Иттриевые лантаноиды отличаются большей подвижностью в водных растворах, что и обусловило не только специфический характер нормированных графиков, но и пониженное по сравнению с гранитоидами фундамента $\mathrm{La} / \mathrm{Yb}$ отношение. Если для гранитов и развитых по ним грейзенам оно колеблется от 8,1 до 48,3, то для углей - от 1,6 до 6,7, в среднем 3,0. Для промышленно германиеносных углей в границах рудного тела и углей за его пределами формы графика однотипны. При этом для рудных участков в целом характерен более крутой угол наклона графика, что, вероятно, обусловлено более значительным вкладом привнесенных в растворах РЗЭ.

Показателен в этом отношении пласт IIІн. В нем наблюдается дренаж современных кислых сульфатных вод, обогащенных $\mathrm{Ge}$, РЗЭ и редкими щелочными элементами. Как следует из табл. 3, угли пласта существенно обогащены РЗЭ на фоне других пластов, особенно значимо тяжелыми лантаноидами и иттрием. При этом на участке германиеносных углей соотношение легких и тяжелых лантаноидов существенно изменено в сторону тяжелых по сравнению с углями за пределами рудного участка (рис. 4, $d$ ). Повидимому, здесь имеет место дополнительное поступление с современными водами зоны гипергенеза и концентрирование в углях $\mathrm{Ge}$ и РЗЭ.

Отчетливо спектр поступающих с водными растворами РЗЭ можно наблюдать на примере углефицированной древесины, извлеченной из песчаников в границах рудного блока (рис. $4, g, h)$. В ископаемой древесине сколько-нибудь значимые содержания РЗЭ могут накопиться только из растворов. Согласно полученным данным, в древесине отмечается накопление всех лантаноидов при отчетливом преобладании тяжелых. Лантан-иттербиевое отношение в данном случае менее 1 (табл. 5). Здесь также сохраняется отрицательная $\mathrm{Eu}$ аномалия на уровне $\mathrm{Eu} / \mathrm{Eu}^{*}=0,54-0,56$

Невысокая, но все же значимая связь Ge с тяжелыми и средними лантаноидами и $\mathrm{Y}$ на уровне $\mathrm{r}=0,39-0,40$ позволяет связать их с единым первичным источником вещества, так же как и W.
Вольфрам. Вольфрам рассматривается как один из главных сопутствующих $\mathrm{Ge}$ элементов в германийугольных месторождениях [9, 10, 17, 18]. Содержание $\mathrm{W}$ в углях в изученных сечениях (табл. 3) превышает средние оценки для углей мира более чем в 200 раз. При этом ореол распространения $\mathrm{W}$ в угольных пластах значительно шире, чем ореол распространения $\mathrm{Ge}$ В углях с рядовым содержанием Ge вблизи месторождения, но за пределами рудных тел, отмечены такие же аномальные содержания $\mathrm{W}$, что и в контуре германиевого оруденения. На соседнем разрезе «Павловский-2» в 1,5-2 км от месторождения Спецугли содержание $\mathrm{W}$ в целом низкое и только на участке поднятия фундамента в прикупольной части вблизи дайки андезитов отмечено наличие аномалий W $(63$ г/т) и Мо (68 г/т). Здесь же повышено содержание $\mathrm{Hg}($ до 1,5 г/т) и $\mathrm{Ge}$ (до 125 г/т).

Очевидно, что содержание $\mathrm{W}$ в угольных пластах прямо связано с его наличием в области питания бассейна угленакопления. При исследовании вольфрамоносных углей Забайкалья и Монголии отмечено, что каким бы способом W не отлагался в углях, его источниками служили рудопроявления и месторождения обрамления угленосных впадин [43]. В Павловском месторождении вольфрамом богаты угли, контактирующие с вольфрамоносными метасоматически измененными гранитами. Отрицательная корреляция содержания $\mathrm{W}$ с зольностью и преимущественно органическая форма его нахождения [44] позволяют говорить о гидрогенном механизме его накопления в углях. Гидрогенный механизм формирования аномалий $\mathrm{W}$ предполагает нахождение источника на сравнительно небольшом расстоянии от места его отложения, так как в гипергенезе ореолы рассеяния его обычно не превышают по протяженности нескольких сотен метров [45]. Выявленные вблизи гранитного выступа редкие включения минеральных фаз вольфрама указывают на возможную роль грейзенизированных гранитов в качестве источника W в углях месторождения Спецугли. На возможность обогащения углей $\mathrm{W}$ за счет метасоматически измененных гранитов указывает и аномально обогащенная им фракция «биотита», полученная из грейзенизированного гранита (табл. 4). Сами граниты фундамента также в 5-10 раз обогащены W по сравнению со средними оценками для аналогичных пород (табл. 2). При этом следует учитывать, что в данном случае представлена только сохранившаяся корневая часть зоны грейзенизации и рудного тела. Не высокая, хотя и значимая корреляция содержания $\mathrm{W}$ и Ge объясняется отличием условий их миграции в водных растворах в процессе транспортировки из коры выветривания в угольный пласт [46].

Сурьма, ртуть и мышьяк. Сурьма отличается аномально высоким содержанием в углях месторождения. Ее концентрации в среднем для изученных пластов превышают кларковое значение для углей в 370 раз, а для пласта ІІн - более чем в 800 раз. Содержание $\mathrm{Sb}$ отчетливо снижается вверх по разрезу аналогично изменению содержания $\mathrm{Ge}$, что обеспечивает их высокую корреляционную связь $(\mathrm{r}=0,90)$. Эти 
данные отличаются от ранее опубликованных сведений по распределению $\mathrm{Sb}$ по пластам в месторождении, полученных на основе изучения керна одной скважины [16].

Содержание $\mathrm{Hg}$ в германиеносных углях месторождения Спецугли также аномально (табл. 4), в среднем превышает угольный кларк в 25 раз, а в пласте IIIн - более чем в 30 раз. В отличие от $\mathrm{Sb}$, содержание $\mathrm{Hg}$ растет вверх по разрезу от 0,78 г/т в пласте IІн до 3,35 г/т в пласте IIIн. В целом для энергетических углей Павловского месторождения характерны невысокие содержания $\mathrm{Hg}$ в пределах 100-200 мг/т. В то же время на участках угольных пластов, приуроченных к метасоматически измененным гранитам, ее концентрация повышается на порядок. В метасоматически измененных гранитах содержание ртути превышает 1 г/т. Ртуть, как и сурьма, показывает высокую корреляционную связь с $\mathrm{Ge}(\mathrm{r}=0,72)$. При этом $\mathrm{Hg}$ показывает невысокую, но значимую корреляционную связь с зольностью $(\mathrm{r}=0,34)$. По-видимому, преобладает органическая форма нахождения $\mathrm{Hg}$, но имеют место и минеральные ее фазы. В частности, выявлены отдельные обломки киновари микронного размера в углях вблизи контакта пласта с корой выветривания гранитов.

Мышьяк сильно обогащает германиеносные угли на фоне энергетических углей. Превышение содержания As в металлоносных углях над рядовыми примерно на порядок, а по сравнению с кларком для углей - в 20 раз. Содержание As, как и $\mathrm{Hg}$, возрастает от нижних пластов к верхним (табл. 3). Мышьяк показывает значимые (выше критического уровня) связи с основной группой элементов-спутников Ge. Коэффициенты корреляции при этом ниже, чем у $\mathrm{Sb}$ и $\mathrm{Hg}$. Наиболее высокий коэффициент ранговой корреляции у $\mathrm{As} \mathrm{c} \mathrm{Hg}(\mathrm{r}=0,77)$, Ge, Mo, Sb, Tl $(\mathrm{r}=0,53)$.

Накопление в углях $\mathrm{Sb}$, As и $\mathrm{Hg}$ происходит, вероятно, преимущественно из водных растворов. Об этом свидетельствует обогащение этими элементами угольных включений в углевмещающих песчаниках (табл. 5). Степень обогащения включений As существенно ниже, чем $\mathrm{Sb}$ и $\mathrm{Hg}$. При этом всеми этими элементами обогащены только угли и угольные включения в границах рудного блока. Энергетические угли бедны ими.

Сурьма и мышьяк, наряду с W, Li, F, Be, Mo, Sn, $\mathrm{Co}, \mathrm{Cu}, \mathrm{Zn}, \mathrm{Pb}$ и Ag, - наиболее характерные элементы для W-Sn-грейзенового типа эндогенного оруденения Приморья [47]. Эта ассоциация с характерной зональностью используется в качестве геохимического критерия при поисках такого оруденения. Из всех элементов-примесей $\mathrm{Sb}$ наиболее тесно связана с $\mathrm{Ge}$ в месторождении Спецугли $(\mathrm{r}=0,91)$.

Радиоактивные элементы (U, Th). Германиеносные угли в 3-5 раз богаче U и в 2-3 раза Th относительно среднего содержания в углях мира (табл. 3). Торий-урановое отношение менее 1 , что указывает на избирательное накопление U, связанное с гидрогенным его поступлением в угольный пласт [48]. Накопление урана в углях месторождения отчетливо связано с наличием здесь в период формирования угленос- ных отложений выступа фундамента, представленного высокорадиоактивными гранитами (табл. 2). Угли, опробованные на удалении от центрального поднятия, отличаются существенно более низкими содержаниями U. Содержание Th в обоих случаях сопоставимо. Это хорошо согласуется с представлением о преимущественно гидрогенном механизме накопления U и кластогенном механизме накопления Тh. Уран образует единую ассоциацию с $\mathrm{Ge}, \mathrm{Sb}, \mathrm{Hg}, \mathrm{As}, \mathrm{Li}, \mathrm{Rb}, \mathrm{Cs}$, $\mathrm{Be}, \mathrm{Se}$ и рядом других, преимущественно халькофильных, элементов. На аквагенную природу поступления части $U$ в угольный пласт указывает и факт его существенного накопления в углефицированной древесине. При этом угольные включения в песчаниках из угленосной толщи обогащены U на порядок больше, чем включения из перекрывающих ее осадков (табл. 5). Одновременно отмечается более слабая, но значимая (выше критического значения) связь с Zr, Hf, $\mathrm{Nb}$ и P3Э $(\mathrm{r}=0,3-0,4)$. Отмечается также положительная связь с зольностью $(\mathrm{r}=0,54)$. Это указывает на двойственную природу накопления $U$ в углях месторождения с преобладанием гидрогенного механизма.

Следует отметить еще один важный факт - наличие, по данным разведочных работ, U оруденения гидрогенного типа в основании угленосных отложений [30]. Рудные тела находятся либо на границе коры выветривания и перекрывающих углистых алевролитов, либо непосредственно в углистых алевролитах. Алевролиты также промышленно германиеносны, хотя беднее $\mathrm{Ge}$, чем вышележащие угольные пласты. Этот факт согласуется с существенно более высокой подвижностью U в процессе выветривания в условиях окислительной среды, чем Ge. Согласно многочисленным исследованиям, потеря U, главным образом «подвижной» формы, происходит на ранних стадиях формирования коры выветривания. Как показали исследования, даже относительно «свежие» граниты при незначительном выветривании могут терять до $70 \%$ U и более [49-52]. Более низкая миграционная способность Th в зоне гипергенеза по сравнению с U приводит к повышению торий-уранового отношения в измененной части гранитов и позволяет отслеживать формирование коры выветривания [53]. Формирование U оруденения происходит на самых ранних стадиях преобразования гранитов фундамента. Этим можно объяснить исключительную связь U оруденения с самыми нижними, соответственно, с самыми ранними по времени формирования осадочными отложениями Павловской впадины. Дальнейшее выветривание гранитов в условиях гумидного климата уже не сопровождалось сколько-нибудь значительным поступлением U в палеоболота. Остаточный U здесь уже представлен в основном в форме акцессориев и поступал в угольный пласт преимущественно как механическая примесь. Этим объясняется не только относительно низкое его содержание в угольных пластах по сравнению с ожидаемым, исходя из аномальной радиоактивности гранитов выступа, но и возросшее торий-урановое отношение. Там, где происходит выветривание гранитов в современных условиях, формируются современные гипергенные аномалии U. 
Однако такие аномалии в углях могут формироваться лишь вблизи области питания, так как восстановительная среда в угольном пласте резко ограничивает миграцию U в водах зоны гипергенеза. Положение месторождения Спецугли на удалении от обрамления Павловской впадины неблагоприятно для накопления $\mathrm{U}$ в угленосных отложениях после формирования угольных пластов и перекрытия осадками выступа гранитного фундамента. В соседнем разрезе «Павловский 2» вблизи границы с обрамлением, сложенным теми же гранитоидами вознесенского комплекса, выявлена аномалия с содержанием 0,23 \% U. При зольности пробы 32,5 \% это составит 0,70 \% в золе угля. Урановая аномалия сопровождается накоплением Мо $(127$ г/т), W (118 г/т) и As (114 г/т). При этом, исходя из факта отсутствия радиоактивного равновесия в ряду распада ${ }^{238} \mathrm{U}$ в изученной пробе, можно заключить, что возраст аномалии U менее 1,7 млн лет [53].

Бериллий - один из типоморфных элементов $\mathrm{Ge}$ оруденения в углях. Он один из первых был отмечен как спутник Ge в германий-угольных месторождениях [10]. Содержание Ве в германиеносных углях месторождения Спецугли достаточно выдержано по разрезу и составляет 54,4 г/т, что более чем в 40 раз выше его среднего содержания в углях мира. Угли за пределами рудного тела тоже существенно обогащены Ве, но коэффициент обогащения вдвое меньше. Ореол Ве, как и $\mathrm{W}$, шире, чем германиевый ореол. Энергетические угли Павловского месторождения существенно беднее Ве, чем угли месторождения Спецугли. Отчетливо просматривается связь обогащения бериллием с гранитным выступом.

Природа обогащения углей Ве не ясна. Опробованный грейзенизированный гранит фундамента хотя и обогащен Ве, но незначительно. В то же время пласты угля аномальны по его содержанию. Можно предположить, что бериллиеносные разности пород находились в верхней части выступа, в настоящее время уничтоженной эрозией. Отсутствие корреляции с зольностью предполагает гидрогенный механизм его накопления в углях. На это указывает и относительная обеднённость бериллием вмещающих угольные пласты осадочных пород. С другой стороны, угольные включения в песчаниках при их аномальности в отношении Ge и других его элементовспутников незначительно обогащены Ве (табл. 5). Исследование форм его нахождения в углях показало, что от 30 до 40 \% Ве в металлоносных углях все же связано с органическим веществом гуминового ряда. Бериллий отличается значимой корреляционной связью с Ge, Li, Cs, W, U, P3Э, Y, Hg, Sb, As, а также Fe и $\mathrm{Na}$.

\section{Основные закономерности распределения германия} и сопутствующих элементов

Несмотря на то, что Ge и все элементы-спутники $\mathrm{Ge}$ оруденения приурочены к гранитному выступу, характер их распределения отличается. Распределение $\mathrm{Ge}$ в месторождении существенно отличается от распределения $\mathrm{W}$ и $\mathrm{Be}$ [20]. Ореол $\mathrm{W}$ и Ве шире, чем ореол Ge. Согласно опубликованным данным, лишь в центральной части месторождения имеются блоки, где ореолы $\mathrm{Ge}, \mathrm{W}$ и Ве в той или иной мере совпадают [20]. Такой характер распределения элементов при отсутствии ярко выраженной зональности свидетельствует о независимом поступлении каждого из этих элементов в угольный пласт. В случае поступления элементов в едином растворе из термального источника обычно имеет место ярко выраженная зональность, обусловленная различной подвижностью элементов, и отчетливо видна их взаимная привязка к зоне разгрузки гидротерм. Например, она показана для торфов Налычевской депрессии на Камчатке, где ореолы отчетливо привязаны к зоне разгрузки гидротерм [9]. Попытка привязать ореолы распределения $\mathrm{Ge}, \mathrm{W}$ и Ве к тектоническим нарушениям, как следует из приведенных схем [20], не увенчалась успехом. К тому же вскрытие месторождения разрезом вплоть до фундамента не подтвердило наличия здесь сколько-нибудь значимых тектонических нарушений возможных проводников гидротерм.

\section{Обсуждение результатов и дискуссия}

Выяснение источника и условий накопления $\mathrm{Ge}$ и сопутствующих ему элементов в углях и углистых породах месторождения Спецугли имеет большое научное и практическое значение, так как эти знания определяют выработку критериев и признаков для выявления подобного оруденения на других территориях. В настоящее время сосуществуют две модели формирования здесь такого оруденения: гидротермальная и гипергенная. Гидротермальная модель обосновывается разгрузкой гипотетических гидротерм, связанных с крупными тектоническими нарушениями в фундаменте с выходом в угленосные отложения в олигоцен-миоценовое время. Она получила наибольшее признание среди геологов с конца XX в. Ее привлекательность обусловлена автоматическим решением проблемы источника $\mathrm{Ge}$ в месторождении. В данной интерпретации источником являются гипотетические флюиды, привносящие $\mathrm{Ge}$ и характерные элементы-спутники в связи с вулканогенногидротермальными процессами в недрах [5, 10-15]. Проводниками таких флюидов являются крупные тектонические нарушения в фундаменте, возникающие или подновленные в период торфо-угленакопления. Проведенные эксплуатационные работы, вскрывшие значительную часть месторождения Спецугли, показали отсутствие каких-либо признаков гидротермальной деятельности в период после формирования коры выветривания по породам фундамента Павловской впадины. Следы гидротермальной деятельности выявлены лишь в связи со становлением гранитного массива вознесенского комплекса, слагающего фундамент, и в более поздний период в связи со становлением дайкового комплекса позднепермского возраста. В обоих случаях разрыв во времени между формированием гидротермально измененных пород (кварц-полевошпатовые метасоматиты и грейзены), связанного с ними редкометалльного оруденения и формированием германий-угольного оруденения составляет более 200 млн лет. На месторождении выяв- 
лено одно мелкое постугольное тектоническое нарушение, но каких-либо следов гидротермальной деятельности в связи с ним не установлено. Да и само нарушение слишком локально. Здесь нет следов катаклаза и милонитизации, тектонических брекчий также не установлено. Содержание $\mathrm{Ge}$ и его спутников в зоне нарушения не повышено относительно других участков пласта. Не выявлено следов вулканической активности синхронной или субсинхронной угленакоплению (эоцен-олигоцен) как в пределах Павловской впадины, так и в ее обрамлении. Пепловые туфы, линзы которых выявлены над угленосной толщей, это привнесенный пирокластический материал, и цирконы из них фиксируют возраст эксплозивных извержений на удалении от впадины. Таким образом, отсутствие каких-либо следов гидротермальной деятельности в пределах вскрытой части месторождения не позволяет рассматривать гидротермальную модель как рабочую.

Приводимые ранее доказательства гидротермальной природы германиевого оруденения такого типа ограничивались спецификой геохимической ассоциации $\mathrm{Ge}$ c W, Be, Sb и As. При этом отмечалось, что характерный набор элементов-спутников не может быть реализован с участием одного углекислоазотного флюида из-за различия свойств элементов, формирующих ассоциацию [5]. Предполагалось, что формирование $\mathrm{Ge}-\mathrm{W}$ и $\mathrm{As}-\mathrm{Hg}-\mathrm{Sb}$ ассоциаций элементов могло происходить из разных гидротермальных источников на разных стадиях рудообразования $[5,17]$. Однако в месторождении Спецугли наиболее тесная связь выявлена между $\mathrm{Ge}$ и $\mathrm{Sb}(\mathrm{r}=0,91)$, что предполагает их совместное отложение. К тому же многостадийность гидротермального рудообразования предполагает не только яркое проявление метасоматической зональности, но и многократное подновление тектонических зон для проникновения металлоносного флюида в верхние горизонты угленосной толщи, что вообще не установлено на изученном участке. Угленосные отложения практически не подвергнуты тектоническим деформациям и не содержат следов гидротермальной деятельности.

В некоторых работах приводились ссылки на наличие в отдельных горизонтах углевмещающих алевропесчаников микропрожилков карбоната, халцедона и хлорита $[16,17]$. В качестве одного из критериев участия гидротермальных вод на примере месторождения Линканг (Китай) отмечено повышенное значение $\delta^{18} \mathrm{O}$ [54]. Как установлено для Кузбасса, длительное взаимодействие содовых вод с углем и алюмосиликатными породами приводит не только к повышению минерализации, но и к существенному сдвигу изотопных отношений в сторону утяжеления $\delta^{18} \mathrm{O}$ на 2-7 \%о и $\delta^{13} \mathrm{C}$ на 25,5-30,7 \%о [55]. Содовые воды - наиболее распространенный тип вод в угольных бассейнах [56]. Высокая значимая корреляционная связь с Na у $\mathrm{Ge}(\mathrm{r}=0,79), \mathrm{Sb}(\mathrm{r}=0,90), \mathrm{Hg}(\mathrm{r}=0,73)$, $\mathrm{U}(\mathrm{r}=0,70)$, As $(\mathrm{r}=0,62)$ и других элементов-спутников германиевого оруденения, формирование редкоземельных карбонатов (бастнезит) в угольных пластах указывает на высокую вероятность участия содовых вод в процессах перераспределения элементов в рудных телах. Гидротермы на месторождении Спецугли ранее связывались с базитовыми дайками кайнозойского возраста (интрузивные аналоги базальтов миоценового возраста), подсеченными скважинами в фундаменте [16, 35]. Как показали настоящие исследования, дайки с редкометалльной минерализацией имеют позднепермский возраст. По ним развита та же кора выветривания, что и по вмещающим их гранитам. Да и состав их, вероятно, не базитовый. Об этом свидетельствует характер графика нормированного на хондрит распределения РЗЭ с четко проявленным европиевым минимумом (рис. 5) $\left(\mathrm{Eu} / \mathrm{Eu}^{*}=0,20\right)$, характерным для пород кислого состава. Для вмещающих дайки гранитов он ещё более контрастный $\left(\mathrm{Eu} / \mathrm{Eu}^{*}=0,13-0,16\right)$.

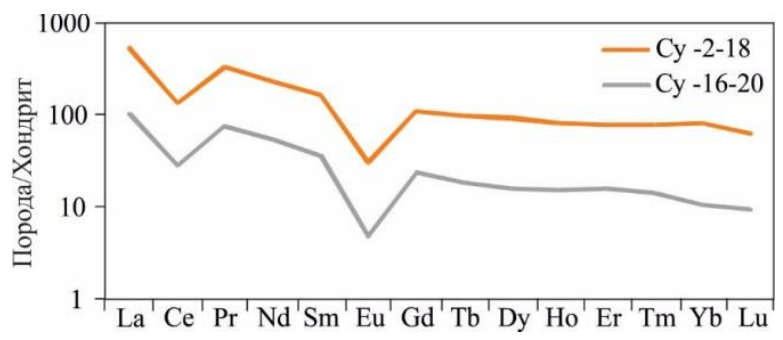

Pис. 5. Нормированные на хондрит по [41] графики распределения РЗЭ в выветрельх дайках фундамента участка Спеиугли (СУ-2-18) и участка «Павловский-2» (СУ-16-20)

Fig. 5. Chondrite-normalized by [41] graphs of the REE distribution in the weathered foundation dikes of the Spetsugli (SU-2-18) and «Pavlovsky-2» (SU-16-20) areas

В ряде исследований признается, что источником $\mathrm{Ge}$ и попутных элементов, как в Спецуглях, так и в месторождении Линканг, являются породы фундамента угленосной впадины, но их поступление в угольный пласт обусловлено участием гидротермальных растворов $[5,14,57,58]$. Следы гидротермальной деятельности неочевидны и представлены редкими новообразованиями сидерита, кальцита, хлорита и каолинита, формирование которых распространено и в условиях зоны гипергенеза без участия гидротерм. Связь редкометалльного оруденения с местными породами для месторождения Линканг доказывается также с использованием изотопных данных [58]. В данном случае отличие гидротермальной модели от классической гипергенной заключается только в участии в этом процессе термальных вод. Известно, что при отсутствии обогащенных $\mathrm{Ge}$ литологических комплексов пород даже при наличии вулканизма германиеносные термы не формируются [46]. Участие флюидов в процессах рудообразования всегда относительно легко распознается по наличию специфических минеральных ассоциаций, гидротермальнометасоматической зональности и текстурноструктурным особенностям. Ничего этого в пределах угленосного чехла на месторождения Спецугли не выявлено. Метасоматические процессы ярко проявлены в фундаменте Павловской впадины, в том числе 
на участке Спецугли, где отчетливо картируется формация кварц-полевошпатовых матасоматитов и грейзенов. Но все эти гидротермально-метасоматические изменения происходили в период, предшествующий формированию коры выветривания в фундаменте, и являются доугольными. Следов посткоровых гидротермальных изменений пород фундамента во вскрытой части месторождения не установлено.

Еще в 1963 г. А.В. Костерин [59] заметил, что для углей Чихезского (Павловского) месторождения характерна очень контрастная отрицательная цериевая аномалия, и интерпретировал это как следствие окисления Се до четырехвалентного состояния и потери его либо в местах выноса или в процессе миграции. В любом случае РЗЭ претерпели этап окисления, прежде чем попали в угольный пласт. Это говорит о наличии коры выветривания по редкометалльным гранитам и дайкам как наиболее вероятном источнике РЗЭ в углях.

Как отмечено в многочисленных работах, вулканогенно-гидротермальные процессы отличаются специфичным поведением европия. Гидротермальные флюиды обычно обогащены Еu относительно трехвалентных РЗЭ [60-64]. На нормированных на хондрит графиках они дают отчетливые положительные аномалии. В некоторых случаях имеют место слабовыраженные отрицательные аномалии европия, которые связывают с процессом взаимодействия флюида с липаритами и дацитами [64]. Современные гидротермы не имеют и цериевого минимума. Слабо выраженная цериевая аномалия со временем формируется в процессе миграции гидротермальных флюидов в условиях зоны гипергенгеза [61, 64]. Как видно из приведенных для месторождения Спецугли данных (рис. 4), во всех случаях для углей, углефицированной древесины из междупластий и дренирующих в германиеносных пластах вод характерно наличие отчетливого европиевого минимума. В случае участия в этих процессах вод, связанных с базитовым магматизмом кайнозоя, имела бы место положительная аномалия $\mathrm{Eu}$ Слабее проявлена отрицательная аномалии церия. Согласно исследованиям, распределение РЗЭ в аутигенных хемогенных и биогенных минералах имеет унаследованный характер, отражая их распределение в аквафациях [65]. Все это свидетельствует о гипергенной природе накопления РЗЭ в углях месторождения за счет вмещающих их пород.

Из обобщенных данных известно, что в водах 30ны гипергенеза вольфрамовых месторождений обнаруживается повышенное содержание весьма широкого комплекса редких и других элементов - W, Mo, Zn, $\mathrm{Cu}, \mathrm{Li}, \mathrm{Rb}, \mathrm{F}, \mathrm{Sn}, \mathrm{Hg}, \mathrm{Sb}, \mathrm{As}[46,66]$. Спектр этих элементов в водах конкретных месторождений определяется минеральным составом руд месторождения и общей металлогенией региона. Полученные нами новые данные о составе останца грейзенизированных гранитов в фундаменте свидетельствуют, что эти породы могут рассматриваться в качестве источника большей части элементов из основной рудной ассоциации. Извлеченная из этих гранитов «биотитовая» фракция фактически представляет из себя редкоме- талльный концентрат (табл. 4). Он аномально обогащен редкими щелочами ( $\mathrm{Li}, \mathrm{Rb}, \mathrm{Cs})$. Минеральное вещество этой фракции обогащено и другой группой элементов-примесей и может рассматриваться как источник в углях $\mathrm{Zn}, \mathrm{Ga}, \mathrm{As}, \mathrm{Y}, \mathrm{Zr}, \mathrm{Nb}, \mathrm{Sn}, \mathrm{Sb}$, лантаноидов, Tl, U и Th. Вклад этой фракции в общий баланс каждого элемента в углях различен, но в большинстве случаев, вероятно, значителен. Установлено, что большинство этих элементов содержится в ней в виде собственных микроминеральных фаз или входит в состав минералов в форме примесей. С этой фракцией связаны достаточно высокие концентрации W. Следует отметить, что изученная фракция извлечена из останца слабо грейзенизированного гранита. Исходя из особенностей зональности кварц-альбитмикроклиновых метасоматитов и грейзенов можно с уверенностью интерпретировать, что гипсометрически выше находились полнопроявленные грейзены, а возможно, и пегматиты, характерные для вознесенского комплекса [26], в настоящее время превращенные в каолиновую кору выветривания. Грейзены, повидимому, содержали W-Мо оруденение и обусловили обогащение углей W, Mo, Sn. На это указывает наличие в останце грейзенизированного гранита молибденита и наличие в углях вблизи гранитного выступа обломков шеелита микронного размера $[22,44]$. Кроме того, в минеральной части угля пласта IIІн на участке непосредственного контакта с гранитным выступом помимо вторичного ангидрита (52-58 \%) преобладает мусковит (17-20\%) и альбит (7-13\%).

Положительная значимая корреляционная связь германия в углях c W, Мо, редкими щелочами и $\mathrm{Be}$ позволяет рассматривать редкометалльные грейзены вознесенского комплекса в качестве основного источника $\mathrm{Ge}$ в углях месторождения Спецугли. Coгласно исследованиям металлоносных грейзенов вознесенского комплекса в обрамлении и за пределами Павловской впадины, для них типично проявление топазовых разностей с содержанием топаза до $20 \%$ [25]. Известно, что топазы отличаются аномально высоким содержанием Ge вплоть до 1500 г/т [38]. Аномально высокое содержание $\mathrm{Sb}$ и при этом тесная корреляционная связь $\mathrm{Ge}$ c $\mathrm{Sb}(\mathrm{r}=0,91)$ позволяют предполагать наличие в источнике $\mathrm{Ge}-\mathrm{Sb}$ минеральных фаз. К таким минералам относятся блеклые руды, типичные для грейзеновых W месторождений. В теннантите содержание $\mathrm{Ge}$ может достигать 0,5 \%. Другие минеральные фазы (молибденит, сфалерит, халькопирит и др.), выявленные в составе грейзенизированных гранитов, также часто являются носителями аномально высокого Ge [38, 67]. В грейзенизированном граните из выступа фундамента на месторождении Спецугли выявлены сульфосоли, содержащие $\mathrm{Sb}$ и As. Помимо этого, Ge характеризуется высокой корреляционной связью с $\mathrm{As}, \mathrm{Hg}, \mathrm{Cd}, \mathrm{Ga}, \mathrm{Y}$ и тяжелыми лантаноидами. Вероятно, этот спектр элементов отражает формирование в породах фундамента гидротермального РЗЭ и сульфидного полиметалльного оруденения, связанного с дайковым комплексом поздней перми. Крупными проявлениями подобной минерализации являются расположенные к северо- 
западу от месторождения Спецугли редкометальные месторождения Вознесенского рудного района.

Гипергенная модель формирования руд месторождения Спецугли на основе имеющейся в настоящее время информации представляется наиболее обоснованной. В составе угля в угольных пластах установлены обломки касситерита, арсенопирита, топаза и киновари. Высокое содержание в углевмещающих песчаниках мусковита и серицита, микроклина, альбита, топаза и других характерных для грейзенов минеральных фаз (касситрита, шеелита) позволяет рассматривать в качестве потенциального источника $\mathrm{Ge}$ и W молибден-вольфрамовые грейзены. Наличие мелких кластогенных форм этих гидротермальных минералов указывает на формирование коры выветривания непосредственно в период накопления массы палеоторфяника. Устойчивость шеелита, вольфрамита и молибденита при выветривании в гумидном климате невелика, поэтому сохранность их минеральных фаз незначительна. Но W хорошо сорбируется органическим веществом торфа, образуя наиболее устойчивые соединения с гуминовыми кислотами и с лигнином. Важно отметить, что W является типоморфным элементом щелочных вод, формирующихся в кристаллических породах $[46,68]$. В условиях щелочной среды он легко выщелачивается из шеелита и несколько хуже из вольфрамита. В кислой среде его подвижность ниже. Этим, вероятно, обусловлено наличие обедненных W железо-марганцевых корок непосредственно в коре выветривания и обогащенных им в угольных пластах вблизи коры выветривания. В первом случае в окислительных условиях вольфрамит легко разрушился, а щелочной раствор способствовал выносу вольфрама. В других условиях частично разложившийся вольфрамит с примесью гидроокислов $\mathrm{Fe}$ и $\mathrm{Mn}$ был перемещен в кислую или околонейтральную восстановительную среду палеоболота и был в ней законсервирован. Такие же фазы образуют $\mathrm{Ge}$ и $\mathrm{Sb}$. Вольфрам в условиях зоны гипергенеза не отличается высокой подвижностью и, как правило, мигрирует на небольшие расстояния, не превышающие нескольких сотен метров [39, 45, 46]. Молибден, как более подвижный элемент в зоне гипергенеза, мигрирует более активно. Его следы выявлены И.Ю. Чекрыжовым на удалении 1,5 км от месторождения Спецугли в основании угленосной толщи разреза Павловский-2. Здесь установлено линзообразное тело, представленное молибденитом и развитым по нему ильземанитом. Аномальное содержание Мо отмечено также в отдельных пробах в золе нижних пластов месторождения. Аномалии Мо выявлены и в углях на контакте с корой выветривания гранита в пределах Павловского месторождения в 2 км к северу от Спецуглей.

Формирование коры выветривания, вероятно, происходило в основном на этапе формирования угленосных отложений. На это указывает наличие в основании угленосной толщи в углистых аргиллитах уранового оруденения [30]. Запасы руд незначительны, поэтому оно рассматривалось как забалансовое. Но сам факт наличия таких руд в составе подстилаю- щих слабопроницаемых отложений свидетельствует о привносе U на стадии их накопления. Приуроченность их к возвышенностям в фундаменте свидетельствует о весьма вероятной их взаимосвязи с выветривающимися гранитами. Так как U обладает высокой подвижностью в зоне гипергенеза и способен выноситься на самых ранних стадиях выветривания гранита, в зрелых корах выветривания его крайне мало. Об этом, в частности, свидетельствует весьма низкое содержание его в коре выветривания гранитов фундамента, опробованных нами на двух разных участках Павловского месторождения. В обоих случаях его содержание не превышает 2 г/т. В то же время относительно свежий гранит, вскрытый в основании центрального поднятия на участке Спецугли, содержит 10-38 г/т урана. По радиогеохимической классификации такие граниты отнесены к группе редкометалльных высокорадиоактивных гранитов.

Таким образом, проведенные исследования свидетельствуют о гидрогенном механизме формирования комплексного редкометалльного оруденения германий-угольного месторождения Спецугли в процессе формирования коры выветривания по грейзенизированным гранитам вознесенского комплекса без участия субсинхронных углеобразованию или постугольных гидротермальных флюидов. На это указывает состав оруденения, формы нахождения германия и сопутствующих элементов, формы рудных тел, минеральная и геохимическая зональность. Формированию месторождения способствовало наличие выступа гранитного фундамента в центре месторождения со специфическим редкометалльным оруденением, развитием по нему каолиновой коры выветривания и благоприятным гидрорежимом в период торфонакопления.

\section{Заключение}

Германий-угольное месторождение Спецугли отличается комплексным составом оруденения. Для металлоносных углей месторождения характерны аномально высокие, превышающие в десятки и даже сотни раз средние содержания для бурых углей мира, концентрации $\mathrm{Ge}, \mathrm{Sb}, \mathrm{Hg}, \mathrm{W}, \mathrm{Li}, \mathrm{Be}, \mathrm{Cs}$, и As. Heсколько менее аномальны уровни накопления U, Mo, $\mathrm{Y}, \mathrm{Rb}$, средних и тяжелых лантаноидов, $\mathrm{Zn}$ и $\mathrm{Ga}$. B связи с этим месторождение может быть оценено как комплексное редкометалльно-угольное. Такой спектр элементов, существенно различающихся по своим свойствам, не может быть сформирован под влиянием одного гидротермального процесса. Такое оруденение может быть либо полигеннополихронным, либо обусловлено гипергенными процессами.

Выполненный комплексный минералогогеохимический и геолого-структурный анализ особенностей состава и строения германий-угольного месторождения Спецугли позволяет пересмотреть принятую гидротермальную модель образования $\mathrm{Ge}$ оруденения в углях и обосновать предложенную ранее гипергенную модель. Полученные результаты хорошо согласуются с гидрогенной гипергенной моде- 
лью образования комплексных германий-угольных месторождений, когда источником металлов являются породы фундамента, вмещающие угольные месторождения

Образование германиевого и сопутствующего ему оруденения в месторождении Спецугли происходило под влиянием формирующейся коры выветривания по гидротермально-метасоматически измененному редкометалльному граниту вознесенского комплекса, прорванному дайками позднепермского возраста. Редкометалльное оруденение отчетливо приурочено к выступу фундамента в центре месторождения, образуя концентрически-зональный ореол $\mathrm{Ge}$ и сопутствующих элементов вокруг него. Характер распределения Ge свидетельствует, что источник металла находился в пределах выступа. Граниты выступа фундамента под-

\section{СПИСОК ЛИТЕРАТУРЬ}

1. Lincang superlarge germanium deposit in Yunnan province, China sedimentation, diagenesis, hydrothermal process and mineralization / H. Zhuang, J. Lu, J. Fu, J. Liu // Journal of China University of Geosciences. - 1998. - V. 9 (2). - P. 129-136.

2. Germanium occurrence in Lincang superlarge deposit in Yunnan, China / H. Zhuang, J. Lu, J. Fu, J. Liu, C. Ren, D. Zou // Science in China Series D: Earth Sciences. - 1998. - V. 41. - P. 21-27.

3. Geochemistry and mineralogy of the Cretaceous Wulantuga highgermanium coal deposit in Shengli coal field, Inner Mongolia, Northeastern China / X. Zhuang, X. Querol, A. Alastuey, R. Juan, F. Plana, A. Lopez-Soler, G. Du, V.V. Martynov // International Journal of Coal Geology. - 2006. - V. 66. - P. 119-136

4. Petrology, mineralogy, and geochemistry of the Ge-rich coal from the Wulantuga Ge ore deposit, Inner Mongolia, China: New data and genetic implications / S. Dai, X. Wang, V.V. Seredin, J.C. Hower, C.R. Ward, J.M.K. O'Keefe, W. Huang, T. Li, X. Li, H. Liu, W. Xue, L. Zhao // International Journal of Coal Geology. - 2012. - V. 90-91. - P. 72-99.

5. Elemental and mineralogical anomalies in the coal-hosted Ge ore deposit of Lincang, Yunnan, southwestern China: Key role of $\mathrm{N}_{2-}$ $\mathrm{CO}_{2}$-mixed hydrothermal solutions / S. Dai, P. Wang, C.R. Ward, Y. Tang, X. Song, J. Jiang, J.C. Hower, T. Li, V.V. Seredin, N.J. Wagner, Y. Jiang, X. Wang, J. Liu // International Journal of Coal Geology. - 2015. - V. 152. - Part A. - P. 19-46.

6. Сапрыкин Ф.Я. Месторождения германия // Рудные месторождения СССР. В 3-х т. / под ред. В.И. Смирнова. Изд. 2-е, перераб. и доп. - М.: Недра, 1978. - Т. 3. - С. 464-471

7. Редкие металлы в буроугольных месторождениях Приморья и их ресурсный потенциал / В.И. Вялов, А.И. Ларичев, Е.В. Кузеванова, А.Х. Богомолов, М.И. Гамов // Региональная геология и металлогения. -2012 . - № 51. - С. 96-105.

8. Вялов В.И., Олейникова Г.А., Наставкин А.В. Особенности распределения германия в углях Павловского месторождения // Химия твердого топлива. - 2020. - № 3. - С. 42-49.

9. Костин Ю.П., Мейтов Е.С. К генезису месторождений высокогерманиеносных углей и критериям их поисков // Известия АН СССР. Серия геологическая. - 1972. - № 1. - С. 112-119.

10. Костин Ю.П., Шарова И.Г., Бурьянов А.В. Закономерности распределения рассеянных элементов в углях одного германий-угольного месторождения // Полезные ископаемые в осадочных толщах. - М.: Наука, 1973. - С. 182-194.

11. Промышленные типы природных концентраций германия В.В. Иванов, А.Я. Кац, Ю.П. Костин, Е.С. Мейтов, Е.Б. Соловьев. - М.: Недра, 1984. -246 с.

12. Левицкий В.В., Седых А.К., Ульсямбаев Ш.Г. Германийугольные месторождения Приморья // Отечественная геология. - 1994. - № 7. - С. 61-67.

13. Seredin V.V., Danilcheva J. Coal-hosted Ge deposits of the Russian Far East // Mineral Deposits at the Beginning of the 21st Century / Eds. A. Piestrynsky et al. - Lisse: Swets \& Zeitlinger Publishers, 2001. - P. 89-92. вергнуты гидротермально-метасоматическим изменениям с формированием кварц-альбит-микроклиновых метасоматитов и грейзенов, содержащих W-Mо и $\mathrm{Hg}-\mathrm{Sb}$-As минерализацию. Метасоматически измененные граниты и дайки подвергнуты поздним гипергенным изменениям с формированием каолиновой коры выветривания, с разрушением первичного эндогенного оруденения и выносом основных элементов в окружающие палеоторфяники. Оба типа эндогенного оруденения в гранитах и дайках проявились в аномальном накоплении W, Mo, Sb, Hg, As, Li, Rb, Cs, Be, U, Y, лантаноидов, $\mathrm{Zn}$ и $\mathrm{Ga}$ в германиеносных углях в эоценолигоценовое время.

Исследование выполнено за счет гранта Российского научного фонда (проект №18-17-00004).

14. Седых А.К. Основные критерии поиска германий-угольных месторождений в приразломных впадинах зон активизации // Геология угольных месторождений. Межвузовский научный тематический сборник. - Екатеринбург: Изд-во Уральской государственной горно-геологической академии, 1999. Вып. 9. - С. 302-311.

15. Petrological, geochemical, andmineralogical compositions of the low-Ge coals fromthe Shengli Coalfield, China: a comparative studywith Ge-rich coals and a formation model for coal-hosted $\mathrm{Ge}$ ore deposit / S. Dai, J. Liu, C.R. Ward, J.C. Hower, P. Xie, Y. Jiang, M.M. Hood, J.M.K. O'Keefe, H. Song // Ore Geology Reviews. - 2015. - V. 71. - P. 318-349.

16. Середин В.В. Аномальные концентрации элементов-примесей в месторождении германия «Спецугли» (Павловское буроугольное месторождение, Южное Приморье). Сообщение 1. Сурьма // Литология и полезные ископаемые. - 2003. - № 2. С. 183-191.

17. Середин В.В. Месторождения германия // Крупные и суперкрупные рудные месторождения / под ред. Н.П. Лаверова, Д.В. Рундквиста. - М.: ИГЕМ РАН, 2006. - Т. 3. - Кн. 2. C. $707-736$

18. Seredin V.V., Finkelman R.B. Metalliferous coals: a review of the main genetic and geochemical types // International Journal of Coal Geology. - 2008. - V. 76. - P. 253-289.

19. Павлюткин Б.И., Петренко Т.И., Чекрыжов И.Ю. Проблемы стратиграфии Павловского угольного поля (Приморье) // Тихоокеанская геология. - 2005. - Т. 24. - № 6. - С. 59-76.

20. Седых А.К. Кайнозойские рифтогенные впадины Приморья (геологическое строение, минерагения и геодинамика углегенеза). - Владивосток: Дальнаука, 2008. - 248 с.

21. Кузеванова Е.М. Металлоносность углей кайнозойских буроугольных месторождений Приморья: автореф. дис. ... канд. геол.-минерал. наук. - СПб., 2014. - 26 с.

22. Арбузов С.И., Ильенок С.С., Чекрыжов И.Ю. Формы нахождения германия и вольфрама в германий-угольном месторождении Спецугли (Дальний Восток) // Известия Томского политехнического университета. Инжиниринг георесурсов. 2020. - T. 331. - № 11. - C. 60-77.

23. Государственная геологическая карта Российской Федерации. Масштаб 1:200000 (второе поколение). Листы L-53-XXXI и K53-I - Вознесенская площадь. - СПб.: Картографическая фабрика ВСЕГЕИ, 2016.

24. Руб М.Г., Руб А.К. Петрология редкометалльных гранитов Вознесенского рудного узла, Приморье // Петрология. 1994. - T. 2. - № 1. - С. 43-67.

25. Руб А.К., Руб М.Г. Редкометальные граниты Приморья. - М.: ВИМС, 2006. - $86 \mathrm{c}$.

26. Кононец С.Н., Валитов М.Г., Изосов Л.А. Вознесенская гранит-риолитовая формация Приморья: проблемы геологии и металлогении // Региональные проблемы. - 2008. - № 10. C. $55-63$.

27. Григорьев Н.А. Среднее содержание химических элементов в горных породах, слагающих верхнюю часть континентальной коры // Геохимия. - 2003. - № 7. - С. 785-792. 
28. Середин В.В. Редкоземельная минерализация в позднекайнозойских эксплозивных структурах (Ханкайский массив, Приморье) // Геология рудных месторождений. -1998. - Т. 40. № 5. - C. 403-418.

29. The plant biostratigraphy of the Cenozoic coal-bearing formations in Primorye, Russian Far East / B.I. Pavlyutkin, T.I. Petrenko, I.Y. Chekryzhov, V.P. Nechaev, T.A. Moore // International Journal of Coal Geology. - 2020. - V. 220. - Article number 103414.

30. Левицкий В.В., Иванов О.А. Подсчет запасов германия Павловского месторождения по состоянию на 01.12.1969 г. Т. 1 Геологоразведочный отчет. - Ярославский, 1969. - 350 с. Росгеолфонд, ЦФ, № 303740.

31. Петрологический атлас ископаемого органического вещества В.И. Вялов, И.Б. Волкова, Г.А. Беленицкая, О.В. Петров, В.Н. Волков, Г.М. Волкова, М.В. Голицын, А.Б. Гуревич, В.М. Богомазов, А.И. Гинзбург, Л.Я. Кизильштейн, В.В. Гальчиков, А.П. Золотов, Г.А. Игнатьев, В.А. Косинский, В.Г. Коломенская, Т.Н. Молозина, Г.М. Парпарова, Н.В. Пронина Г.В. Соколова, С.В. Щербакова. - СПб.: Изд-во ВСЕГЕИ, 2006. $-604 \mathrm{c}$

32. Угольная база России. T. V. Кн. 1. Угольные бассейны и месторождения Дальнего Востока (Хабаровский край, Амурская область, Приморский край, Еврейская АО). - М.: ЗАО «Геоинформмарк», 1997. - $371 \mathrm{c}$

33. Аналитические подходы к количественному определению содержаний химических элементов в углях и углистых породах с использованием методов ИСП МС и ИНАА / Н.В. Зарубина, М.Г. Блохин, Д.С. Остапенко, И.Ю. Чекрыжов, С.И Арбузов., А.Ф. Судыко // Известия Томского политехнического университета. Инжиниринг георесурсов. - 2021. - Т. 332. - № 3. C. $99-112$.

34. Середин В.В. Аномальные концентрации элементов-примесей в месторождении германия «Спецугли» (Павловское буроугольное месторождение, Южное Приморье). Сообщение 2. Рубидий и цезий // Литология и полезные ископаемые. 2003. - № 3. - С. 279-287.

35. Середин В.В. Редкоземельные элементы в германиеносных пластах месторождения «Спецугли» (Приморье, Россия) // Геология рудных месторождений. - 2005. - Т. 47. - № 3. С. 265-283.

36. Вялов В.И., Наставкин А.В., Шишов Е.П. Особенности распределения сопутствующих германию промышленно ценных микроэлементов в углях Павловского месторождения (участок «Спецугли») // Химия твердого топлива. - 2021. - № 1. C. $17-28$.

37. Ketris M.P., Yudovich Ya.E. Estimations of Clarkes for Carbonaceous biolithes: world average for trace element contents in black shales and coals // International Journal of Coal Geology. - 2009. - V. 78. - P. 135-148.

38. Геологический справочник по сидерофильным и халькофильным редким металлам / В.В. Иванов, О.Е. Юшко-Захарова Л.Ф. Борисенко, Л.Н. Овчинников. - М.: Недра, 1989. - 462 с.

39. Чечель Л.П. Распределение редких щелочных элементов в водах горнорудных объектов Восточного Забайкалья // Геосферные исследования. - 2020. - № 4. - С. 98-107.

40. The unique Abramovka REE-rich mineralization is a potential source of REE for the Pavlovsk coals deposit (Primorsky Krai, Russia) / I. Chekryzhov, I. Tarasenko, E. Vakh, S. Vysotsky // E3S Web of Conferences. - 2019. - V. 98. - Article number 01007.

41. Taylor S.R., McLennan S.M. The continental crust: its composition and evolution. - Oxford: Blackwell Scientific Publications, 1985. - $312 \mathrm{p}$.

42. Seredin V.V., Dai S. Coal deposits as potential alternative sources for lanthanides and yttrium // International Journal of Coal Geology. - 2012. - V. 94. - P. 67-93.

43. Осокин П.В. О распределении элементов-примесей в углях Северной Монголии и Южного Забайкалья // Литология и полезные ископаемые. - 1993. - № 2. - С. 113-120.

44. Modes of occurrence of germanium and tungsten in the Spetsugli germanium ore field, Pavlovka brown coal deposit, Russian Far East / S.I. Arbuzov, D.A. Spears, S.S. Ilenok, I.Y. Chekryzhov, V.P. Ivanov // Ore Geology Reviews. - 2021. - V. 132. - Article number 103986.

45. Крайнов С.Р., Капранов С.Д., Петрова Н.Г. Основные особенности геохимии вольфрама в подземных и поверхностных во- дах районов вольфрамовых месторождений // Геохимия. 1965. - № 10. - С. 1234-1245.

46. Крайнов С.Н. Геохимия редких элементов в подземных водах. - М.: Недра, 1973. - 296 с.

47. Рудоконтролирующие факторы и оценка перспектив вольфрамоносности отдельных территорий центрального СихотеАлиня / Б.М. Шашорин, А.И. Макаров, Е.В. Матвеева, Д.Е. Выдрич // Разведка и охрана недр. - 2019. - № 5. - С. 8-18.

48. Geochemistry of radioactive elements (U, Th) in coal and peat of northern Asia (Siberia, Russian Far East, Kazakhstan, and Mongolia) / S.I. Arbuzov, A.V. Volostnov, L.P. Rikhvanov, A.M. Mezhibor, S.S. Ilenok // International Journal of Coal Geology. - 2011. - V. 86. - P. 318-328.

49. Smellie J.A.T., Stuckless J.S. Element mobility studies of two drill-cores from the Götemar Granite (Kråkemåla test site), southeast Sweden // Chemical Geology. - 1985. - V. 51. - P. 55-78.

50. Geochemical and petrological studies of a uraniferous granite from the Granite Mountains, Wyoming / J.S. Stuckless, C.M. Bunker, C.A. Bush, W.P. Doering, J.H. Scott // Journal of Research of the U.S. Geological Survey. - 1977. - V. 5. - P. 61-81.

51. Stuckless J.S., Nkomo I.T. Uranium-lead isotope systematics in uraniferous alkali-rich granites from the Granite Mountains, Wyoming; implications for uranium source rocks // Economic Geology. - 1978. - V. 73. - P. 427-441.

52. Stuckless J.S., Nkomo I.T. Preliminary investigations of U-Th-Pb systematics in uranium-bearing minerals from two granitic rocks from the Granite Mountains, Wyoming // Economic Geology. 1980. - V. 75. - P. 289-295.

53. Титаева Н.А. Геохимия природных радиоактивных рядов распада. - М.: ГЕОС, 2005. - 226 с.

54. Geological and geochemical constraints on the origin of the giant Lincang coal seam-hosted germanium deposit, Yunnan, SW China: a review / R.-Z. Hu, H.-W. Qi, M.-F. Zhou, W.-C. Su, X.-W. Bi, J.-T. Peng, H. Zhong // Ore Geology Reviews. - 2009. - V. 36. P. 221-234.

55. Лепокурова О.Е. Содовые подземные воды юга Кузбасса: изотопно-химические особенности и условия формирования // Геохимия. - 2018. - № 9. - С. 904-919.

56. Lepokurova O.E. Sodium-bicarbonate groundwaters in southeastern West Siberia, Russia: compositions, types, and formation conditions // Applied Geochemistry. - 2020. - V. 116. Article number 104579.

57. Enrichment of germanium and associated arsenic and tungsten in coal and roll-front uranium deposits / B. Etschmann, W. Liu, K. Li, S. Dai, F. Reith, D. Falconer, G. Kerr, D. Paterson, D. Howard, P. Kappen, J. Wykes, J. Brugger // Chemical Geology. - 2017. V. 463. - P. 29-49.

58. Strontium isotopes in high- and low-Ge coals from the Shengli Coalfield, Inner Mongolia, northern China: new indicators for Ge source / J. Liu, B.F. Spiro, S. Dai, D French., I.T. Graham, X. Wang, L. Zhao, J. Zhao, R. Zeng // International Journal of Coal Geology. - 2021. - V. 233. - Article number 103643.

59. Костерин А.В., Королев Ф.Д., Кизюра В.Е. Редкие земли в Чихезском буроугольном месторождении // Геохимия. 1963. - № 7. - C. 594-595.

60. Haas J.R., Shock E.L., Sassani D.C. Rare earth elements in hydrothermal systems: Estimates of standard partial molal thermodynamic properties of aqueous complexes of the rare earth elements at high pressures and temperatures // Geochimica et Cosmochimica Acta. - 1995. - V. 59. - P. 4329-4350.

61. Hydrogeochemistry and rare earth element behavior in a volcanically acidified watershed in Patagonia, Argentina / C.H. Gammons, S.A. Wood, F. Pedrozo, J.C. Varecamp, B.J. Nelson, C.L. Shope, G. Baffico // Chemical Geology. 2005. - V. 222. - P. 249-267.

62. Чудаева В.А., Чудаев О.В. Особенности накопления и фракционирования редкоземельных элементов в поверхностных водах Дальнего Востока в условиях природных и антропогенных аномалий // Геохимия. - 2011. - № 5. - С. 523-549.

63. Geochemical processes assessed by rare earth elements fractionation at «Laguna Verde» acidic-sulphate crater lake (Azufral volcano, Colombia) / C. Inguaggiato, V. Burbano, D. Rouwet, G. Garzon // Applied Geochemistry. - 2017. - V. 79. P. 65-74. 
64. Карпов Г.А., Николаева А.Г., Алехин Ю.В. Содержание и источники редкоземельных элементов в современных вулканогенных гидротермальных системах Камчатки // Петрология. 2013. - T. 21. - № 2. - C 163-176.

65. Holser W.T. Evaluation of the application of rare-earth elements to paleoceanography // Palaeogeography, Palaeoclimatology, Palaeoecology - 1997. - V. 132. - P. 309-323.

66. Замана Л.В., Чечель Л.П., Абрамова В.А. Гидрогеохимия зоны техногенеза рудных месторождений Восточного Забайкалья // Геологическая эволюция взаимодействия воды с горными породами: Материалы III Всероссийской научной конференции с международным участием. - Улан-Удэ: Изд-во БНЦ СО PAH, 2018. - C. 39-46.

67. Bernstein L.R. Germanium geochemistry and mineralogy // Geochimica et Cosmochimica Acta. - 1985. - V. 49. - P. 2409-2422

68. Крайнов С.Н., Рыженко Б.Н., Швец В.М. Геохимия подземных вод. Теоретические прикладные и экологические аспекты. - М.: ЦентрЛитНефтеГаз, 2012. - 672 с.

Поступила 12.04.2021 г.

\section{Информация об авторах}

Арбузов С.И., доктор геолого-минералогических наук, профессор отделения геологии Инженерной школы природных ресурсов Национального исследовательского Томского политехнического университета.

Чекрыжов И.Ю., научный сотрудник лаборатории геохимии Дальневосточного геологического института ДВО РАН

Ильенок $\boldsymbol{C . C . , ~ к а н д и д а т ~ г е о л о г о - м и н е р а л о г и ч е с к и х ~ н а у к , ~ а с с и с т е н т ~ о т д е л е н и я ~ г е о л о г и и ~ И н ж е н е р н о и ̆ ~ ш к о л ы ~}$ природных ресурсов Национального исследовательского Томского политехнического университета.

Соктоев Б.P., кандидат геолого-минералогических наук, доцент отделения геологии Инженерной школы природных ресурсов Национального исследовательского Томского политехнического университета.

Соболева E.E., ведущий инженер по охране окружающей среды, РУ «Новошахтинское» ООО «Приморскуголь». 
UDC 553.493:550.42

\title{
NEW DATA ON GEOCHEMISTRY AND GENESIS OF THE SPETSUGLI GERMANIUM-COAL DEPOSIT (PRIMORSKY KRAI)
}

\author{
Sergey I. Arbuzov 1 , \\ siarbuzov@mail.ru \\ Igor Yu. Chekryzhov², \\ chekr2004@mail.ru
}

Sergey S. llenok', ilenokss@tpu.ru

\section{Bulat R. Soktoev1,} bulatsoktoev@tpu.ru

Elena E. Soboleva ${ }^{3}$, SobolevaEE@suek.ru

${ }^{1}$ National Research Tomsk Polytechnic University, 30, Lenin avenue, Tomsk, 634050, Russia.

2 Far East Geological Institute FEB RAS,

159, 100-leyita Vladivostoka avenue, Vladivostok, 690022, Russia.

${ }^{3}$ Novoshakhtinskoe surface mine office, 000 Primorskugol,

29 , Tigrovaya street, 690090 , Vladivostok, Russia.

The relevance of this research is conditioned by the need to develop predictive and prospecting criteria for identifying a strategically important type of germanium raw material - germanium-coal deposits.

The main aim is to study the geochemical features and conditions for the formation of complex rare-metal mineralization in coals of the Spetsugli deposit (Far East) and by this example develop a geological-geochemical model of the formation of deposits of similar type.

Objects: coal, coal-bearing rocks, underground waters and basement rocks of the germanium-coal deposit.

Methods: geological and geochemical sampling, inductively coupled plasma mass spectrometry, instrumental neutron activation analysis, scanning electron microscopy, optical microscopy, $X$-ray phase analysis, correlation analysis.

Results. New data on the geological structure and geochemistry of coals and coal-bearing rocks in the Spetsugli germanium-coal deposit in the Primorsky Krai were obtained. The complex polyelement composition of rare-metal mineralization in the deposit is explained. It is consistent with geochemistry and minerageny of basement rocks and the framing of the Pavlovsk depression. Anomalously high concentrations of $\mathrm{Ge}, \mathrm{Sb}$, $\mathrm{Hg}, \mathrm{W}, \mathrm{Li}, \mathrm{Be}, \mathrm{Cs}$, and As are typical in metalliferous coals; they are tens and hundreds of times higher than the average content in lignite worldwide. The accumulation levels of $U, M o, Y, R b, R E E, Z n$ and $\mathrm{Ga}$ are somewhat less anomalous. The complex mineralogical-geochemical and geological-structural analysis of the composition and structure of the Spetsugli Ge-coal deposit made it possible to reevaluate the accepted hydrothermal model of Ge mineralization in coals. It also helped to validate the previously proposed hypergene model, which states that the sources of metals are basement rocks hosting coal deposits. The pre-Cenozoic age of endogenous rare-metal mineralization in granites of the basement was substantiated. The formation of $\mathrm{Ge}$ and accompanying mineralization in the Spetsugli deposit was influenced by the forming weathering crust over the rare-metal granite of the Voznesensky complex cut by dikes of the Late Permian age. The deposit is confined to a granite upland, forming a concentric-zonal halo of $\mathrm{Ge}$ and associated elements around it. Granites underwent hydrothermal and metasomatic alteration which resulted in quartz-albite-microcline metasomatites and greisens containing W-Mo and $\mathrm{Hg}$-Sb-As mineralization. Rare-metal mineralization in coals is associated with the formation of kaolin weathering crust over granites, removal and redeposition of basic elements in the surrounding peat paleo-bogs in the Paleogene.

\section{Key words:}

Germanium-coal deposit, coal, geochemistry, rare elements, rare-metal mineralization, conditions of formation, hydrogenous model.

The research was carried out under the support of the grant of the Russian Science Foundation (Project no. 18-17-00004).

\section{REFERENCES}

1. Zhuang H., Lu J., Fu J., Liu J. Lincang superlarge germanium deposit in Yunnan province, China: sedimentation, diagenesis, hydrothermal process and mineralization. Journal of China University of Geosciences, 1998, vol. 9 (2), pp. 129-136.

2. Zhuang H., Lu J., Fu J., Liu J., Ren C., Zou D. Germanium occurrence in Lincang superlarge deposit in Yunnan, China. Science in China Series D: Earth Sciences, 1998, vol. 41, pp. 21-27.

3. Zhuang X., Querol X., Alastuey A., Juan R., Plana F., Lopez-Soler A. Du G., Martynov V.V. Geochemistry and mineralogy of the Creta- ceous Wulantuga high-germanium coal deposit in Shengli coal field, Inner Mongolia, Northeastern China. International Journal of Coal Geology, 2006, vol. 66, pp. 119-136.

4. Dai S., Wang X., Seredin V.V., Hower J.C., Ward C.R., O'Keefe J.M.K., Huang W., Li T., Li X., Liu H., Xue W., Zhao L. Petrology, mineralogy, and geochemistry of the Ge-rich coal from the Wulantuga Ge ore deposit, Inner Mongolia, China: new data and genetic implications. International Journal of Coal Geology, 2012, vol. 90-91, pp. 72-99.

5. Dai S., Wang P., Ward C.R., Tang Y., Song X., Jiang J., Hower J.C., Li T., Seredin V.V., Wagner N.J., Jiang Y., Wang X., Liu J. 
Elemental and mineralogical anomalies in the coal-hosted Ge ore deposit of Lincang, Yunnan, southwestern China: key role of $\mathrm{N}_{2^{-}}$ $\mathrm{CO}_{2}$-mixed hydrothermal solutions. International Journal of Coal Geology, 2015, vol. 152, P. A, pp. 19-46.

6. Saprykin F.Ya. Mestorozhdeniya germaniya [Germanium deposits]. Rudnye mestorozhdeniya SSSR [Ore deposits of USSR]. In 3 vol. Ed. by V.I. Smirnov. Moscow, Nedra Publ., 1978. Vol. 3, pp. 464-471.

7. Vyalov V.I., Larichev A.I., Kuzevanova E.V., Bogomolov A.Kh., Gamov M.I. Rare metals in the brown coal deposits of Primorye and their resource potential. Regional geology and metallogeny, 2012, vol. 51, pp. 96-105. In Rus.

8. Vyalov V.I., Oleinikova G.A., Nastavkin A.V. Distribution of germanium in coals of the Pavlovsk deposit. Solid Fuel Chemistry, 2020, vol. 54, pp. 163-169.

9. Kostin Yu.P., Meitov E.S. K genezisu mestorozhdeniy vysokogermanienosnykh ugley i kriteriyam ikh poiskov [On the genesis of high-germanium coal deposits and the criteria for their forecast]. Proceedings of USSR Academy of Sciences. Geology, 1972, vol. 1, pp. 112-119.

10. Kostin Yu.P., Sharova I.G., Buryanov A.V. Zakonomernosti raspredeleniya rasseyannykh elementov v uglyakh odnogo germaniy-ugolnogo mestorozhdeniya [Regularities of the scattered elements distribution in the coals of one germanium-coal deposit]. Poleznye iskopaemye $v$ osadochnykh tolschakh [Mineral deposits in sedimentary strata]. Moscow, Nedra Publ., 1973. pp. 182-194.

11. Ivanov V.V., Kats A.Ya., Kostin Yu.P., Meitov E.S., Solovyev E.B. Promyshlennye tipy prirodnykh kontsentratsiy germaniya [Types of germanium industrial mineral deposits]. Moscow, Nedra Publ., 1984. $246 \mathrm{p}$.

12. Levitskiy V.V., Sedykh A.K., Ulsyambaev Sh.G. Germaniyugolnye mestorozhdeniya Primorya [Germanium-bearing coal deposits of Primorye]. National Geology, 1994, vol. 7, pp. 61-67.

13. Seredin V.V., Danilcheva J. Coal-hosted Ge deposits of the Russian Far East. Mineral Deposits at the Beginning of the 21st Century. Ed. by A. Piestrynsky. Lisse, Swets \& Zeitlinger Publishers, 2001. pp. 89-92.

14. Sedykh A.K. Osnovnye kriterii poiska germaniy-ugolnykh mestorozhdeniy $\mathrm{v}$ prirazlomnykh vpadinakh zon aktivizatsii [Main forecast criteria for germanium-coal deposits in fault-line depressions of the activation zones]. Geologiya ugolnykh mestorozhdeniy [Coal deposits geology]. Ekaterinburg, Ural State Mining and Geological Academy Publ. House, 1999. Vol. 9, pp. 302-311.

15. Dai S, Liu J., Ward C.R., Hower J.C., Xie P., Jiang Y., Hood M.M., O'Keefe J.M.K., Song H. Petrological, geochemical, andmineralogical compositions of the low-Ge coals fromthe Shengli Coalfield, China: a comparative studywith Ge-rich coals and a formation model for coal-hosted Ge ore deposit. Ore Geology Reviews, 2015, vol. 71, pp. 318-349.

16. Seredin V.V. Anomalous trace elements contents in the Spetsugli germanium deposit (Pavlovsk brown coal deposit, Southern Primorye). P. 1. Stibium. Lithology and Mineral Resources, 2003, vol. 2, pp. 183-191. In Rus.

17. Seredin V.V. Mestorozhdeniya germaniya [Germanium deposits]. Krupnye $i$ superkrupnye rudnye mestorozhdeniya [Large and super-large ore deposits]. Eds. N.P. Laverov, D.V. Rundkvist. Moscow, Institute of Geology of Ore Deposits, Petrography, Mineralogy and Geochemistry RAS Publ., 2006. Vol. 3, P. 2, pp. 707-736.

18. Seredin V.V., Finkelman R.B. Metalliferous coals: a review of the main genetic and geochemical types. International Journal of Coal Geology, 2008, vol. 76, pp. 253-289.

19. Pavlyutkin B.I., Petrenko T.I., Chekryzhov I.Yu. The problems of the stratigraphy of the Pavlovka coal-field tertiary deposits, Primorye. Russian Journal of Pacific Geology, 2005, vol. 24, no. 6, pp. 59-76. In Rus.

20. Sedykh A.K. Kaynozoyskie riftogennye vpadiny Primorya (geologicheskoe stroenie, minerageniya $i$ geodinamika uglegeneza) [Cenozoic rift basins of Primorye (geological structure, mineralogy and geodynamics of coal formation)]. Vladivostok, Dalnauka Publ., 2008. 248 p.

21. Kuzevanova E.M. Metallonosnost ugley kaynozoyskikh burougolnykh mestorozhdeniy Primorya. Avtoreferat Dis. Kand. nauk [Metal content in coals of Cenozoic brown coal deposits, Primorye. Cand. Diss. Abstract]. St. Petersburg, 2014. 26 p.
22. Arbuzov S.I., Ilenok S.S., Chekryzhov I.Yu. Modes of occurrence of germanium and tungsten in the Spetsugli germanium ore field (Russian Far East). Bulletin of the Tomsk Polytechnic University. Geo Assets Engineering, 2020, vol. 331, no. 11, pp. 60-77. In Rus.

23. Gosudarstvennaya geologicheskaya karta Rossiyskoy Federatsii. Masshtab 1:200000 (vtoroe pokolenie). Listy L-53-XXXI i K-53-I Voznesenskaya ploshchad [State geological map of the Russian Federation. Scale 1:200000 (second edition). Chart sheets L-53XXXI and K-53-I - Vosnesenskaya area]. St. Petersburg, Cartographic enterprise of A.P. Karpinsky Russian Geological Research Institute, 2016

24. Rub M.G., Rub A.K. Petrology of rare-metal granites of the Voznesensky ore node, Primorye. Petrology, 1994, vol. 2, no. 1, pp. 43-67. In Rus.

25. Rub A.K., Rub M.G. Redkometalnye granity Primorya [Raremetal granites of Primorye]. Moscow, All-Russian ScientificResearch Institute of Mineral Resources named after N.M. Fedorovsky Publ.g House, 2006. 86 p.

26. Kononets S.N., Valitov M.G., Izosov L.A. Voznesenskaya graniterhyolite formation of Primorye: problems of geology and metallogeny. Regional problems, 2008, no. 10, pp. 55-63. In Rus.

27. Grigor'ev N.A. Average concentrations of chemical elements in rocks of the upper continental crust. Geochemistry International, 2003, vol. 41, no. 7, pp. 711-718.

28. Seredin V.V. Rare earth mineralization in late Cenozoic explosion structures (Khankai massif, Primorskii Krai, Russia). Geology of Ore Deposits, 1998, vol. 40, no. 5, pp. 357-371.

29. Pavlyutkin B.I., Petrenko T.I., Chekryzhov I.Y., Nechaev V.P., Moore T.A. The plant biostratigraphy of the Cenozoic coalbearing formations in Primorye, Russian Far East. International Journal of Coal Geology, 2020, vol. 220, article number 103414.

30. Levitskiy V.V., Ivanov O.A. Podschet zapasov germaniya Pavlovskogo mestorozhdeniya po sostoyaniyu na 01.12.1969 g. T. 1 . Geologorazvedochny otchet [Germanium reserve assessment in Pavlovsk deposit as on 01.12.1969. Vol. 1. Geological survey report]. Yaroslavskii, 1969. 350 p. Rosgeolfond, TsF, No. 303740

31. Vyalov V.I., Volkova I.B., Belenitskaya G.A., Petrov O.V., Volkov V.N., Volkova G.M., Golitsin M.V., Gurevich A.B., Bogomazov V.M., Ginzburg A.I., Kizilshtein L.Ya., Galchikov V.V., Zolotov A.P., Ignatiev G.A., Kosinsky V.A., Kolomenskaya V.G., Molozina T.N., Parparova G.M., Pronina N.V., Sokolova G.V., Scherbakova S.V. Petrologicheskiy atlas iskopaemogo organicheskogo veshchestva [Petrological atlas of fossil organic matter of Russia]. St. Petersburg, A.P. Karpinsky Russian Geological Research Institute Publ. House, 2006. 604 p.

32. Ugolnaya baza Rossii. T. V. Kn. 1. Ugolnye basseyny i mestorozhdeniya Dalnego Vostoka (Habarovskiy kray, Amurskaya oblast, Primorskiy kray, Evreyskaya AO) [Coal base of Russia. Vol. V, P. 1. Coal basins and deposits of Far East (Khabarovsk Krai, Amur Oblast, Primorski Krai, Jewish Autonomous Oblast)]. Moscow, Geoinformmark Publ., 1997. 371 p.

33. Zarubina N.V., Blokhin M.G., Ostapenko D.S., Chekryzhov I.Yu., Arbuzov S.I., Sudyko A.F. Analytical approaches to the quantitative determination of the chemical elements concantrations in coals and carbonaceous rocks using ICP MS and INAA. Bulletin of the Tomsk Polytechnic University. Geo Assets Engineering, 2021, vol. 332, no. 3, pp. 99-112. In Rus.

34. Seredin V.V. Anomalous trace elements contents in the Spetsugli germanium deposit (Pavlovsk brown coal deposit, Southern Primorye). P. 2. Rubidium and cesium. Lithology and Mineral Resources, 2003, vol. 3, pp. 279-287. In Rus.

35. Seredin V.V. Rare earth elements in germanium-bearing coal seams of the Spetsugli deposit (Primor'e region, Russia). Geology of Ore Deposits, 2005, vol. 47, no. 3, pp. 238-255.

36. Vyalov V.I., Nastavkin A.V., Shishov E.P. Distribution of industrially valuable trace elements associated with germanium in the coals of the Pavlovsk deposit (Spetsugli section). Solid Fuel Chemistry, 2021, vol. 55, pp. 14-25.

37. Ketris M.P., Yudovich Ya.E. Estimations of Clarkes for Carbonaceous biolithes: world average for trace element contents in black shales and coals. International Journal of Coal Geology, 2009, vol. 78, pp. 135-148.

38. Ivanov V.V., Yushko-Zakharova O.E., Borisenko L.F., Ovchinnikov L.N. Geologicheskiy spravochnik po siderofilnym i khalkofil- 
nym redkim metallam [Geological handbook of siderophilic and chalcophilic rare metals]. Moscow, Nedra Publ., 1989. 462 p.

39. Chechel L.P. Distribution of rare alkaline elements in water mining objects of the Eastern Transbaikalia. Geosphere Research, 2020, vol. 4, pp. 98-107. In Rus.

40. Taylor S.R., McLennan S.M. The continental crust: its composition and evolution. Oxford, Blackwell Scientific Publications, 1985. $312 \mathrm{p}$.

41. Chekryzhov I., Tarasenko I., Vakh E., Vysotsky S. The unique Abramovka REE-rich mineralization is a potential source of REE for the Pavlovsk coals deposit (Primorsky Krai, Russia). E3S Web of Conferences, 2019, vol. 98, Article number 01007.

42. Seredin V.V., Dai S. Coal deposits as potential alternative sources for lanthanides and yttrium. International Journal of Coal Geology, 2012, vol. 94, pp. 67-93.

43. Osokin P.V. On the distribution of trace elements in the coals of Northern Mongolia and Southern Transbaikalia. Lithology and Mineral Resources, 1993, vol. 2, pp. 113-120. In Rus.

44. Arbuzov S.I., Spears D.A., Ilenok S.S., Chekryzhov I.Y., Ivanov V.P. Modes of occurrence of germanium and tungsten in the Spetsugli germanium ore field, Pavlovka brown coal deposit, Russian Far East. Ore Geology Reviews, 2021, vol. 132, Article number 103986.

45. Kraynov S.R., Kapranov S.D., Petrova N.G. Osnovnye osobennosti geokhimii volframa $\mathrm{v}$ podzemnykh i poverkhnostnykh vodakh rayonov volframovykh mestorozhdeniy [The main features of the tungsten geochemistry in underground and surface waters in areas of tungsten deposits]. Geokhimiya, 1965, no. 10, pp. 1234-1245.

46. Kraynov S.R. Geokhimiya redkikh elementov v podzemnykh vodakh [Geochemistry of rare elements in groundwater]. Moscow, Nedra Publ., 1973. 296 p.

47. Shashorin B.N., Makarov A.I., Matveeva E.V., Vydrich D.E. Orecontrolling factors and estimation of wolframtones individual territories Central Sikhote-Alin. Prospect and protection of mineral resources, 2019, no. 5, pp. 8-18. In Rus.

48. Arbuzov S.I., Volostnov A.V., Rikhvanov L.P., Mezhibor A.M., Ilenok S.S. Geochemistry of radioactive elements $(\mathrm{U}, \mathrm{Th})$ in coal and peat of northern Asia (Siberia, Russian Far East, Kazakhstan, and Mongolia). International Journal of Coal Geology, 2011, vol. 86 , pp. 318-328.

49. Smellie J.A.T., Stuckless J.S. Element mobility studies of two drill-cores from the Götemar Granite (Kråkemåla test site), southeast Sweden. Chemical Geology, 1985, vol. 51, pp. 55-78.

50. Stuckless J.S., Bunker C.M., Bush C.A., Doering W.P., Scott J.H Geochemical and petrological studies of a uraniferous granite from the Granite Mountains, Wyoming. Journal of Research of the U.S. Geological Survey, 1977, vol. 5, pp. 61-81.

51. Stuckless J.S., Nkomo I.T. Uranium-lead isotope systematics in uraniferous alkali-rich granites from the Granite Mountains, Wyoming; implications for uranium source rocks. Economic Geology, 1978, vol. 73, pp. 427-441.

52. Stuckless J.S., Nkomo I.T. Preliminary investigations of U-Th-Pb systematics in uranium-bearing minerals from two granitic rocks from the Granite Mountains, Wyoming. Economic Geology, 1980, vol. 75, pp. 289-295.

53. Titaeva N.A. Geokhimiya prirodnykh radioaktivnykh ryadov raspada [Geochemistry of natural radioactive decay series]. Moscow, GEOS Publ., 2005. 226 p.

54. Hu R.-Z., Qi H.-W., Zhou M.-F., Su W.-C., Bi X.-W., Peng J.-T., Zhong $\mathrm{H}$. Geological and geochemical constraints on the origin of the giant Lincang coal seam-hosted germanium deposit, Yunnan, SW China: a review. Ore Geology Reviews, 2009, vol. 36, pp. 221-234.
55. Lepokurova O.E. Sodic groundwaters in the Southern Kuznetsk basin: isotopic and chemical characteristics and genesis. Geochemistry International, 2018, vol. 56, no. 9, pp. 934-949.

56. Lepokurova O.E. Sodium-bicarbonate groundwaters in southeastern West Siberia, Russia: Compositions, types, and formation conditions. Applied Geochemistry, 2020, vol. 116, Article number 104579

57. Etschmann B., Liu W., Li K., Dai S., Reith F., Falconer D., Kerr G., Paterson D., Howard D., Kappen P., Wykes J., Brugger J. Enrichment of germanium and associated arsenic and tungsten in coal and roll-front uranium deposits. Chemical Geology, 2017, vol. 463, pp. 29-49.

58. Liu J., Spiro B.F., Dai S., French D., Graham I.T., Wang X, Zhao L, Zhao J., Zeng R. Strontium isotopes in high- and low-Ge coals from the Shengli Coalfield, Inner Mongolia, northern China: New indicators for Ge source. International Journal of Coal Geology, 2021, vol. 233, Article number 103643.

59. Kosterin A.V., Korolev F.D., Kizyura V.E. Redkie zemli v Chikhezskom burougolnom mestorozhdenii [Rare-earth elements in Chikhez brown coal deposit]. Geokhimiya, 1963, no. 7, pp. 594-595. In Rus.

60. Haas J.R., Shock E.L., Sassani D.C. Rare earth elements in hydrothermal systems: Estimates of standard partial molal thermodynamic properties of aqueous complexes of the rare earth elements at high pressures and temperatures. Geochimica et Cosmochimica Acta, 1995, vol. 59, pp. 4329-4350.

61. Gammons C.H., Wood S.A., Pedrozo F., Varecamp J.C., Nelson B.J., Shope C.L., Baffico G. Hydrogeochemistry and rare earth element behavior in a volcanically acidified watershed in Patagonia, Argentina. Chemical Geology, 2005, vol. 222, pp. 249-267.

62. Chudaeva V.A., Chudaev O.V. Accumulation and fractionation of rare earth elements in surface waters of the Russian Far East under the conditions of natural and anthropogenic anomalies. Geochemistry International, 2011, vol. 49, no. 5, pp. 498-524.

63. Inguaggiato C., Burbano V., Rouwet D., Garzon G. Geochemical processes assessed by rare earth elements fractionation at «Laguna Verde» acidic-sulphate crater lake (Azufral volcano, Colombia). Applied Geochemistry, 2017, vol. 79, pp. 65-74.

64. Karpov G.A., Nikolaeva A.G., Alekhin Y.V. Abundances and sources of rare-earth elements in the modern volcanogenic hydrothermal systems of Kamchatka. Petrology, 2013, vol. 21, no. 2, pp. $145-157$.

65. Holser W.T. Evaluation of the application of rare-earth elements to paleoceanography. Palaeogeography, Palaeoclimatology, Palaeoecology, 1997, vol. 132, pp. 309-323.

66. Zamana L.V., Chechel L.P., Abramova V.A. Gidrogeokhimiya zony tekhnogeneza rudnykh mestorozhdeniy Vostochnogo Zabaykalya [Hydrogeochemistry of the zone of technogenesis of ore deposits Eastern Transbaikalia]. Geologicheskaya evolyutsiya vzaimodeystviya vody s gornymi porodami. Materialy III Vserossiyskoy nauchnoy konferentsii s mezhdunarodnym uchastiem [Geological evolution of water-rock interaction. Proc. of III AllRussian scientific conference]. Ulan-Ude, Buryat Scientific Centre SB RAS Publ. House, 2018. pp. 39-46.

67. Bernstein L.R. Germanium geochemistry and mineralogy. Geochimica et Cosmochimica Acta, 1985, vol. 49, pp. 2409-2422.

68. Kraynov S.N., Ryzhenko B.N., Shvets V.M. Geokhimiya podzemnykh vod. Teoreticheskie, prikladnye i ekologicheskie aspekty [Geochemistry of underground waters. Theoretical, applied and environmental aspects]. Moscow, TsentrLitNefteGaz Publ., 2012. $672 \mathrm{p}$.

Received: 12 April 2021.

\section{Information about the authors}

Sergey I. Arbuzov, Dr. Sc., professor, National Research Tomsk Polytechnic University.

Igor Yu. Chekryzhov, researcher, Far East Geological Institute FEB RAS.

Sergey S. Ilenok, Cand. Sc., assistant, National Research Tomsk Polytechnic University.

Bulat R. Soktoev, Cand. Sc., assistant professor, National Research Tomsk Polytechnic University.

Elena E. Soboleva, lead engineer for environmental protection, Novoshakhtinskoe surface mine office, OOO Primorskugol. 